$\left[\begin{array}{l}1916 \\ H 18\end{array}\right)$

Hamilton.

Classification Of The Larvae Of Ground Beeties 



\section{CLASSIFICATION OF THE LARVAE OF GROUND BEETLES}

BY

CLYDE CARNEY HAMILTON

B. S. Kansas State Agricultural College, 1913

THESIS

Submitted in Partial Fulfillment of the Requirements for the

Degree of

MASTER OF SCIENCE

IN ENTOMOLOGY

IN

THE GRADUATE SCHOOL

OF THE

UNIVERSITY OF ILLINOIS

1916 



\section{U N I VER S I T Y O F I L L I NOIS \\ THE GRADUATE SCHOOL}

$\frac{0}{0}$

June 2. $\quad{ }_{191}^{6}$

I HEREBY RECOMMEND THAT THE THESIS PREPARED UNDER MY SUPER-

VISION BY

Clyde carney Hamilton

ENTITLED Tho Glassification of the Iarrese of Ground

\section{Beet2os}

BE ACCEPTED AS FULFILLING THIS PART OF THE REQUIREMENTS FOR THE. DEGREE OF. Mastor of Science

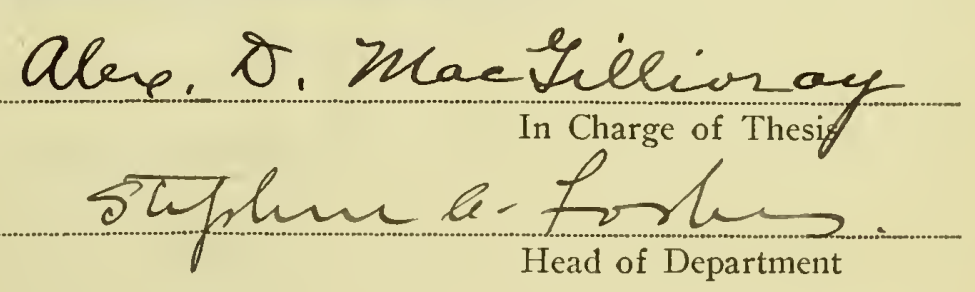

Recommendation concurred in :*

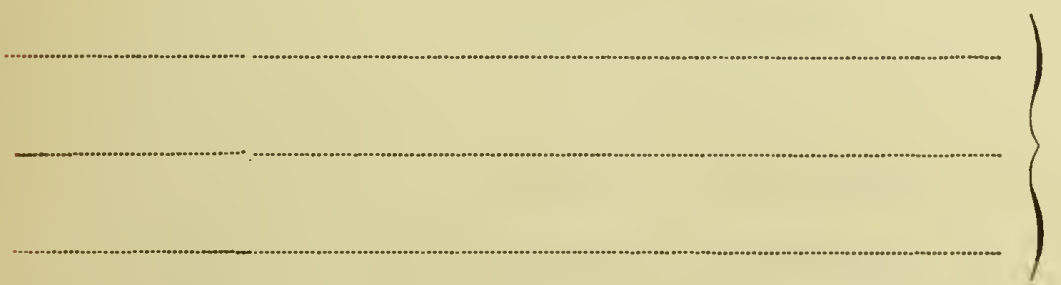

\section{Committee}

on

Final Examination*

*Required for doctor's degree but not for master's. 
Digitized by the Internet Archive in 2014 
Table of Contents.

Introduction $\ldots \ldots \ldots \ldots \ldots \ldots \ldots \ldots \ldots \ldots \ldots \ldots \ldots \ldots \ldots \ldots \ldots \ldots$

Charactors usod in classification $\ldots \ldots \ldots \ldots \ldots \ldots \ldots \ldots \ldots \ldots \ldots \ldots \ldots$

Lifo history and habits of the larvae $\ldots \ldots \ldots \ldots \ldots \ldots \ldots \ldots \ldots \ldots \ldots . . . \ldots$. Classification

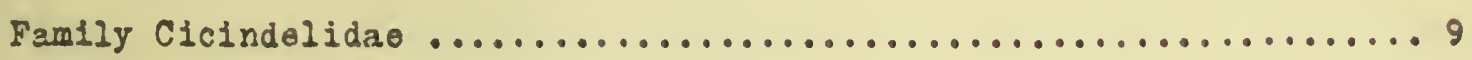

Table for determining the genera of Cicindolidae .......... 10

Gonus Cicindela ............................. II

Table for determining the species of the genus

Cicindela $\ldots . . . \ldots \ldots \ldots . . . \ldots . . . . .13$

Cicindola 6 -guttata $\ldots \ldots \ldots \ldots \ldots \ldots \ldots \ldots . . . . . .16$

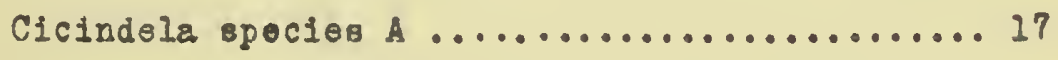

Cicindela purpurea var. limbalis ........... 19

Cicindela purpurea var. gramirea .......... 21

Cicindola latosignata ..................22

Cicindela species B ...................23

Cicindela ropanda .................... 24

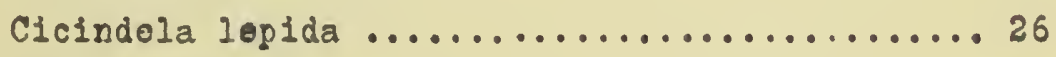

Clcindela grationa .................... 8

Cicindola tranguebarica .................29

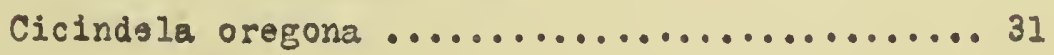

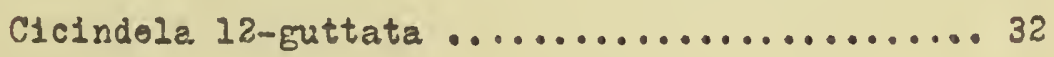

Cicindola punctulata ......................... 34

Cicindela llavopunctata var. rectilatara .......36

Cicindela unipunctata ...................... 37

Cicindela abdominalis $\ldots \ldots \ldots \ldots \ldots \ldots \ldots . . . . .38$ 

Cicindela mareinata $\ldots . . . \ldots \ldots \ldots . . . . .39$

Cicindela formosa ..................4 4

Cicirdela formosa var. generosa ...........4 42

Cicindela scutollaris var. lecontel ........44 44

Cicirdola pulchre ...................45

Cicindela limbata $\ldots \ldots \ldots \ldots \ldots \ldots \ldots \ldots$

Cicindela hirticoliis ................ 48

Cicindola dorealis var. saulcyi .......... 50

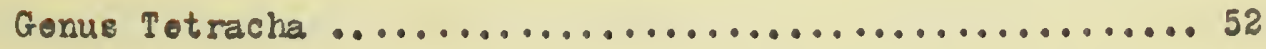

Table for determining the species of the genus

Totracka ..................... 53

Tetracha carolina .................... 53

Tetracha virginica $\ldots \ldots \ldots \ldots \ldots \ldots \ldots \ldots \ldots$

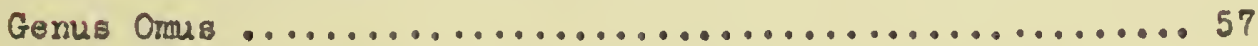

Table for determining the species of the genus

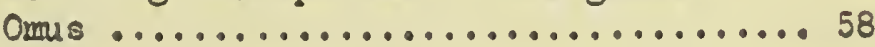

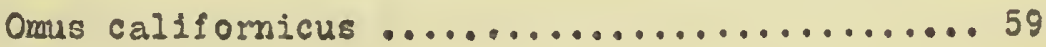

Omus ambiguus $\ldots \ldots \ldots \ldots \ldots \ldots \ldots \ldots \ldots . \ldots . \ldots 60$

Onus sequoiarum ......................61

Gonus Amblychila ...........................64 64

Amblychila cylindriformis .................65

Blbliography $\ldots \ldots \ldots \ldots \ldots \ldots \ldots \ldots \ldots \ldots \ldots \ldots \ldots \ldots \ldots \ldots \ldots \ldots \ldots \ldots \ldots \ldots$ 



\section{INTRODUCTION}

A study of the immature tages of insects offers excoptional opportum 1ties for original resoarch of a now, extremely interesting and profitablo naturs. In spite of the fact that, in the vast majority of insects, it is tho young or growing stage which is of oconomic importance, comparativoly littlo connected systematic work has been done upon them. The Cicindelidae aro no exception to this statoment. The larvae wers first noted in literaturs as early as 1798 by Goeffry, and occassional reforences have been made sinco then from time to time. The first work of any importance in America was done by Go0. H. Horn in 1878. He gives a detailod description of a larva from oach of the lour genera occuring in the United States. His descriptions, howevor, aro too general to bo of much taxononic value. During the same year and several succooding yoars F. G. Schaup published a number of notes on tigerbootlo larvae. Fron this time until about 1905 very littlo attention was given to the study of the larvae. In $1907 \mathrm{~V}$. E. Shelford published in the Blological Bulletin an excellent account of the habits and distribution of a number of the species occuring in the vicinity of Chicago, Illinois. The following year ho gublishod on the life-history and habits of these same spocies and considorod their relation to hibornation, depth of burrow, moisturs, temperaturo, -tc. In later papers ho has made dotailed comparisons of tho ocology of the larve of the same specios and of different spocies fron widely soparatad rogions. In 1907 and 1910 Norman Criddle publishod in the Canadian Entomologist very good accounts of the habits and lifo-historios of a number of the spocies occuring in Manitoba; Canada. Somo of the moro interesting lacts ho pointed out are the increased depth of the burrows, the smaller size of the spocies and the lengthoning of the lifs-history, due to the long severe wintors and short summers. An interesting paper on the habits of Amblychila 

cyl Indriformis was printed in the Entomological Nows for 1914 by F. B. Williams and H. B. Hungorford. The most comprehonsive work on all stages of the Cicindelldae, however, is that of Waltor Horm publishod in tho Genera Insectoruk. Ho discusses practically ovory phaso of the subjact, as classification, morgh ology, lifo-history, ocology, coloration, otc., and includos a comploto biblia graphy under each species.

The purpose of the present work is to describe the morphology of the larvas and to homologize tho parts, to give analytical table for the identification of species occuring in the Unitod States so far as material was availablo, and to describo each spociss and its habitat. Mang of tho adults ars vory similar and difficult to separate and a similar condition is found in tho study bof the larvao. Numerous drawing have been prepared to make the characters by which the larva aro separatsd as cloar as possiblo and to savo detailed descriptions.

The study of the immature stages of any group of insects necessitates a considerablo amount of work in collecting and roaring matorial for identification. This is ospocially groat in tho family Cicindelidas whoro tho larvas are very restrictod in their habitat, and a number of tho spocios aro limited in thoir distribution. The present study bras mado possiblo thru tho opportunity for the Graduate School of the University of Illinois to purchase a collection of identified larvae froin Dr. V. E. Sholford. Thanks aro due him for permission to use his unpublished notes, for numerous suggestions on the habits of the larvae, and for holp in securing additional material. Tho work has boon carrisd on under the diroction of Professor . A. D. NacGillivray to whon especial thanks aro due for his holpful suggestions and criticisms. The scope of this paper has boen considerably extended by the opportunity to atudy a collection of the larvae of the genus Oraus, togother with some additionel larvae of the goaus Cicindela, presented to the University of 

Illinols by $\mathrm{Dr}$. F. F. Blaisdell Sr. of the Leland Stanford Junior Universitf. Modical School. Thanks are due Mins Alice Ritchie, Hagerman, Idaho and ur. 2. H. Vanoe, Southorn Pinos, North Carolina for collecting larvae to bo reared. 

The morphology and taxonomy of the immature stages of many insects prosent difficultios greater than those oncountered in the aduits becauss a considerable part of the body is oither membranous or slightly chitinizod. In the larva of the Cicindelidae the majority of the taxonomic characters ars found on the head, the pronotum, and the fifth abdominal segment. Some of these structures are quite constant while othors vary within cortain limits, It has seomed advisablo, therefore, to give a general discussion of the characters used.

All measurements have been made with a binocular microscope and an eyo-piece microneter. While in many species the difforence botweon corresponding parts is not groat, it is constant onough to be of considerable value. One of the best uses which can be rado of mossuremonts, as has been determined by a number of workers upon various species of insects, is the proportional length of one distance to another. This proportion is constant for individuals of different sizes of the samo species and often for the lifferent instars. The proportional longth and width of the fronto-clypeo-labral area, the prom portional diameter of ocellus 2 to the distance betweon ocolli 1 and 2 , the proportional length of the segments of the antenna, and the longth and width of the pronotum aro all good charactors. In goneral, ocelli 1 and 2 , the homology of which is indicated in Figs. 5 \& 8 , aro vory much the same size in the large and small specios of the genus Cicindela, but they appear to be larger in the smaller epecies, due to the smaller size of the hoad. As a result the distance botroon ocolli 1 and 2 is genorally less than the diamoter of ocellus 2 in the smaller species. The proportional length of the segments of the maxillary palpus and of the labial palpus furnish excollent generic characters but does not vary onough to be of spocific value. The position of 



\section{5}

the cophalomlateral angles of the pronotum with rospect to the cophalomesal part and the general shape of the pronotum varies considerably in the spocies of the genus Cicindela.

The character, number, and position of the setae on the head, pronotum and abdoreen provides further characters for separating the species. The setae on the U-shaped ridge at the caudal part of the front in the genus Cicindela are very constant in number for those species which have only $\%$, but in those spocies which have throe an extra seta or two may occassionally be present. In the species of Tetracha there are always three setae on the transverse ridge at the caudal part of the front. In Owas, however, there is always a single large sota on the middlo of this transverse ridge and one or two smaller setae on each side. The setae on the first and second segments of the antenna vary within tho limits given in the descriptions but is usually not more than one on either side of the average. The number of setae on the mesal margin of the proximal segment of the galea is quite constant for all species of the genera Cicindela, Tetracha, and Omus.

In the genera Cicindela and Tetracha the setao are very similar in nutber and arrangement in the first larval instar. These aro the primary setae (Figs.49852) and are generally the larger and more prominent setae of the mature larvae. The setao which ars added at the first and socond molts are considered as secondary sotae. In the genus Onus the arrangement of the primary setae (Fig.82) is slightly different from that of the two genera named. No larvas of the first or second instars of the genus Amblychila were studied but the arrangement of the setae on the pronotum of the mature larva would seem to indicate that the arrangement and number of the primary setae aro difforent from that of the other gonera studied. The grimary sotao have been designated by nurebers but the secondary setae are too numerous and irregular innumber and arrangement to apply mubers to them. In those species 

In which the secondary setae are not numerous the sotal plan of the second and third instars is generally the same, while in those specios which have a largo number of secondary setae a part ars added at the first molt and the remainder at the socond. The secondary setao vary in number and position in difforent Individuals of the same species but used in connection with other structures they provide excellent charactors for separating the species.

The setae on the chitinized arsas of the abdomen aro very similar in number and arrangement for the first instar of all species of the genera Cicindela and Omus (FIgs.88\&91) In which the first larval stages wero studied. These setao have boen designated as primary sotae and those sotao which aro added at the first and second molts as sosondary eotae. In giving the setal plan of the abdorien, the third segment has boon used since it soems to bo the least likely to be modified. The setae on the hooks of the fifth abdominal. segment are constant in number in thoso spocies which have two, but vary in those specios which have three or zoore.

The dorsal aspoct of the head and pronotum is very highly colorsd in many spocies and, within cortain limits, furrishos oxcollent means for separating them. The color is of two kinds, pigmental and physical. The pigmental colors are dull, usually some shade of brown, and appear the same whon examined from any angle. The physical colors aro much brighter and are produced by small pit-like depressions. These colors vary with the angle from which the specimen is examined. The surface, when examined with a strong light, may show any of the following colors; purple, purplish-bronze, coppery, copporybronze, bronze, blus, or grean. When viewed from an acute anglo the blue or greon color is usually more pronounced and this is spoken of as the color which is reflected. 

The larva of this family diffor from the larvae of most other gredacm ous Insects in that thoy live in a definito fixed burrow and lie in wait for thoir proy to cone within reach. The majority of predacous insects have no definite abode, or if thoy do, they go out in search of their grey. The habite of the tiger-beetle larvae make them dependant ugon chance for their food supply and undoubtedly it is vory irregular and at times not flontiful. As a result the length of the larval instars may vary considerably, depending upon the food supply, temperature, and the length of the growing or feeding season.

The Iffe-history of different species of Cicindela as given by

Sholford (1908) for northern Illinois is of three typos and is as follows;

"(a) Eggs laid in late spring or early sumner, larvae hibernate usually in the third stage, fupate in the second sumer; imagoes emergo about a month after pupation, hibernate, and becorus sexually mature late in the third spring, -- larval lifo lasts twolve to thirteen months, adult life ten months, -- two years between generations.

(b) Eggs laid in mid summer, larvae hibernate usually in the third stage, pupate in the following June; imagoss emerge in early July and become sexulily ature very soon, - larval life ten months, adult life two months, -- one year between generations.

(c) Eggs laid in mid-summer; larvae hibernato in the second stage, reach the third stage early in the second sumer, hibernate again, and pupate in the fllowing May; imagoes emerge in the early part of the third suremer and become sexually mature soon, - larval life twenty-one months, adult life two months, - two years between generations".

That the time spent in the larval stage is influenced by temperature, length of the summer or growing season, and possibly other factors is shown 

by Criddie (1910);

"It $w i l l$ be noticed, however, that there is a striking differenoo in the life-cycle of some of the species, observed by Prof. Sholford at Chicago and those noted by me at Aweme, even when the same, or a closely related form, is irvolved, the difference boing the prolongation of the larval life over a socond winter in Manitoba. This seomed to be such a remarkablo fact, considering that there aro less than 600 miles of latitude between the two places, that I lelt almost persuaded that some mistake had beon made on my part, and consequently decided to make further investigation bofore fublishing these notes. The results have been to loave no doubt that the lifocycle of spectes carefully observed -- C. Manitoba, venusta, limbata. limbalis, and probably others - lasts for approximately threo years; duration of larval otage 24 to 26 months, pupal two to four woeks, adult, 10 to 12 monthe".

Many of the larvae are very restricted in thoir habitat, occuring only in particular kinds of soil and requiring a certain amount of moisture. Cicindela duodecimguttata, repanda, and hirticolis loave their burrows if the soil becores too dry and seek new places which are sufficiently molst. The female oviposits in small holes about ono centiveter deep in soil which is suitable for the development of the larvae. The larva, upon hatching, deopens and widens this burrow and lives in it unless-conditions become unfavorable for its development. Before each molt the larva closes the burrow, goos to the bottom, molts and reappears again in about one week. There are only throe instars in the larval cycle. When the larva is ready to pupate it makes a pupal chamber or burrow, generaliy at one side of the main burrow, in which it pupates. The depth of the larval burrow, whether it is perpendicular to the surface, spiral, or slanting, and the charactor of the pupal chamber, is characteristic for each species. 



\section{CLASSIFICAT ION}

As previously stated comparatively littlo connocted systematic ork has beon done on the immature etages of insects. The vast majority of descriptions of cleopterous larvae are of economic species which have been deecribed by ocononic workers. As a result thoy vary considerably with respect to the characters mentioned and in many inotances it is almost impossible to draw definite conclusions as to sore of the structures described.

\section{Family Cicindelidao}

Larvae of medium length, cylindrical; hoad and pronotum strongly chitinized, wider than the remainder of the body and inclined ventro-cephalad; hoad concave on the dorsal aspect, strongly convex on the ventral; clypeus and labrux fused with the front; ocelli, four or six on each side of the head, ocelli 1 and 2 largor than the others, ocolli 5 and 6 sometimes aboent; antenna four-segmented; mandibles sicklo-shaped with a prominent tooth on the middle of the mesal margin, inclined dorso-cophalad at an anglo of about $45^{\circ}$; maxilla with the cardo more or less triangular, stifes considerably longer than wide, galea two-segmented, proximal seguent of the galea and the palpifer fused, maxillary palpus two-or threersegmented, lacinia sometimes present; labium with the labial palpus two-regmented; pronotum large, shield-shacod, heavily chitinized and fitting close againet the caudal margin of the head; logs long, tarsus with two claws, the cephalic claw longer than the caudal; abdomen with ten distinct segments, fifth segment with a dorsal protuberance boaring two or three pair of hooks; anal cerci wanting; spiracles present on the mosothorax and the first oight abdominal segronts.

The characters of the larvae have been determined from the examination of specimens representing the four genera occuring in the United States 

and ons genus, Collyris, an arboreal form occuring in tho gtoms of coffec plante on the Island of Java.

Table for Determining the Genera of Cicindelidae.

A. Ocelli 1 and 2 subequal in sizo.

B. Nodian hooks long, curved, and sickle-chaped with the convox side towards the mon; mesal hooks short, cylirdrical, and usualiy with the distal ond suddenly constricted into a spinowike projection; ridge on the caudal part of the front U-shagod and not joining the ridge on the caudal part of the vertex; lablal palfus with a distinct chitinizod sclerits at its proximal end, proximal segment with two or three spine-like projections on its ventro-distal margin.

Cicindela.

BB. Median hooks thorn-like, straight or very elightly curved towards the meson; mesal hooks similar in shape to the modian hooks and about one-half as long; ridge on the caudal part of tho front transverge and joining the ridge on the caudal part of tho vertex; labial palpus without a chitinized sclerite at its groximal ond, proximal segment without spino-1ike projections on its ventradigtal margin.

Tetracha.

A. Ccollus 2 considerably smallor than ocellus 1.

B. Antonna not separated from the mandiblo by a transverse, chitinized bar, second sogment not twice as long as the firet; labial palfus with a distirct chitinized sclerito at its proximal ond, proximal segment with a single spine-like projection on its ventro-distal margin, proximal segment longer than the distal segment; fifth abdominal segment bearing throe pairs of hooks on the doreal aspect. 

BB. Antenna segaratod from the mandible by a transverse chitinized bar, socond sogment twice as long as the first; lebial palpus without a chitinized sclorito at its proximal ond, proximal sogment withcut spine-like projections on its ventro-distal wargin, first segment shorter than the second; fifth abdominal segment bearing two gairs of hooks on the dorsel aspoct.

Amblychila.

\section{Genus Cicindela Linn.}

Head with the ridge on the caudal part of the front U-ahaped and not cortimuous whth the ridge on the caudal part of the vertex; antecoxal piece of tho mandible distinct, rectengular; cophalic nargin of the labrum smootb; ocolld 1 and 2 subogual in 6120 , ocoll1 3 larger than 4 and not adjacont, ocelli5 and $6 \mathrm{small}$ and Inconspicuous; antenna not soparated from the mandiblo by a transverse chitinized bar, second segment one-half the total longth of tho othor:; maxilla with tho cardo triangular and boaring a singlo sota, lacinia absent, maxillary palfus with two or three segmente, the first segment the shortest, the second slightfy lorger than the first, and the third the longest, second segment without a spinowike projection on the latero-diatal margin; labium not chitinized on the ventral aspect cophalad and moad of the labial palpi, ventral aspect not concave and not forning a carina on the caudal and latoral margins; ligula with the two sotae noar the middlo close together; labial palyus with a soparate chitinized sclerite at ito proximal ond, proximal segment longer than tho distal and with two or three spino-like projections on its ventro-distal margin, tho cproximal segment with four or five cetao and tho distal segment with ono; fifth abdominal segment with twe- pairs of hooks on the doreal aspect, tho latoral hooks wanting; median hooks long, slonder, and 

sickle-shapod with the concave side laterad and with ono to four sotae; mosal hooks skort, cylindrical, and constricted at the distal end into a sharp spine and with two to twelve setae.

Tho genus Cicindela contains a largo numbor of spocios and subspocios, more than one hundred having been described from the United States. Many of these are widely distributed and the species present a considerable variation in the range of the characters of the larvae. Among the species described horo there aro several, the identity of which is not cortain and a sew wich aro unknown. They are included, however, with the hope that larvae may lator bo reared and their identity establishod. 

Table for Dotermining the Spocios of the Gonus Cicindola.

A. Maxillary palpus with thrse sogments.

B. U-shapod ridge on the caudal part of front bouring two distinct sotao.

C. Mesal hooks never with more than two setae on the shoulder; setao on hoad and pronotum usually whito, rarely transparont or bropn.

D. Pronotum chestnut brown.

E. Setae on head and pronotum brown; head same color as pronotum; pronotum without a color pattern............... 6-guttata.

EE. Setae on head and pronotum whits; head bronze; pronotum with a color pattorn of lightor aroas..............................

DD. Pronotum not chestnut brown.

E. Modian hooks with ono or two sotae, if with throo, ono sota much smaller than the others.

F. Mesal hooks with the spine-like projection ono-third or more the entire length of the hook.

G. Mesal hooks with the spino-like projection more than ono-half tho ontirs length of the hook........... purvurga limbalis.

GG. Hosal hooks with the spine-like projection one-half or less than the entire longth of the hook.

H. Pronotum with the secondary setae wanting except a single largo one cophalo-laterad of sota $4 \ldots$ purpurea graminoa.

HH. Pronotum with the secordary sotas small, twenty or more in number.

I. Ninth abdominal sternurs with the caudal margin bearing two groups of throe sotae sach.............. latesionata.

II. Ninth abdominal sternum with the caudal margin bearing two groups of four setae each............... Species B.

FF. Mosal hooks with tho apino-like projection never more than onesixth the entirs length of the hook.

G. Pronotum with the secondary setae $f$ ow, not moro than ten in number; antenna with the first segment bearing ten or oleven sotae; median hooks with a singlo large seta, if two ars present one much amaller than the othor.......... repanda.

GG. Pronotum with the secondary setas nunerous, fifty or coors in. number; antonna with the first segment bearing sevon or - Ight sotas; median hooks with two sotas.......... lopida.

EE. Modian hooks with threo sotao. 

F. Mosal hooks with the spino-1ike projection about ono-8ixth the ontire longth of the hook, the sotao inserted on a broad shouldor; pronotum with the mosal portion of the cophallc margin oxtonding distinctly cophalad of tho cophalo-lateral anglog

gratiosa.

FF. Mosal hooks with the spino-like projection about ono-third or more the entire length of the hook, the sotao insortyd on a sloping shoulder; pronotum with the mosal portion of the cophalic margin not oxtonding distinctly cophalad of the cophalo-lateral anglos.

G. Ninth abdominal sternum with the caudal margin bearing two groups of four sotao oach................ tranquobarica.

GG. Ninth abdominal stornum with tho caudal margin boaring two groups of throo setao oach.

H. Antenna with the first sogment bearing oight to oloven sotao.

I. Pronotum with the socondary setae twenty-five or thirty in number and with a row on each side of the meson, the blue roflection very strong.................. oregona.

II. Pronotum with the secondary sotas not more than ton in numbor and not with a row on each side of the moson, the blue roflection not strong.................. 12-guttata.

HH. Antenna with the first egment bearing five or six sotae.

I. Hoad and pronotum bronzo with a slight bluo roflection; diameter of ocellus 2 loss than the distance botwosn ocolli 1 and $2 \ldots \ldots \ldots \ldots \ldots$ punctulata.

I. Head and pronoturn dark purplo with a green or blue reflection; diameter of ocolius 2 subequal to or greater than the distance botroen ocelli 1 and $2 . . . \ldots \ldots \ldots \ldots . . . .$.

\section{llavopunctata roctilatera.}

CC. Mesal hooks with mors than two setas on the shoulder; sotas on head and pronotum transparent or glassy.

D. Pronotum with the cophalo-lateral angles oxtonding distinctly cophalad of the mosal portion of the coghalic margin..... uninunctata.

DD. Pronotum tith the cephalo-lateral angles not oxtending cophalad of the mosil portion of the cophallc margin.

E. Mosal hooks boaring throo prominent sotao, the spine-like projection almost obsoloto....................... abdominalis.

EDE. Mosal hooks bearing ton or eleven prominent sotao, the spine-like projoction distinct..................... marginata. 

BB. U-shaped ridge on the caudal part of front boaring threo or four distinct setae.

C. Proxinal segment of the galoa with four stout sotac on the mesal margin: head and pronotum light brown; diameter of ocellus 2 distinctly less than the distance between ocel11 1 and 2 .

D. Modian hooks bearing two distinct sotae; average width of hoad and pronotum $4.5 \mathrm{~mm} \ldots \ldots \ldots \ldots \ldots \ldots \ldots \ldots \ldots \ldots$ formosa.

DD. Yodian hooks boaring threo distinct setas; average width of hoad and pronotum $4.0 \mathrm{~mm} . . \ldots \ldots \ldots \ldots . . \ldots \ldots$ formosa genorosa.

CC. Proximal segment of the galea with throe stout setae on the mesal margin; hoad and pronotum bronze or coppory colored; diameter of ocellus 2 subequal to or greater than the distance betwoen ocolli 1 and 2.

D. Mesal hooks boaring more than two sotao....... scutellaris locontoi.

DD. Mosal hooks boaring two sotae.

E. Pronotum with the secondary setae for, not ovor ton, fine, and inconspicuous, and with the cophalo-lateral anglos extending as far cophalad as the mosal portion............... pulchra.

EE. Pronotum with the socondary sotae numerous, mor than fifty, flat and prominent, and with the cephalo-lateral angles not extendigg as far cophalad as tho mosal portion.

F. Modian hooks with throe distinct setae; pronotum with the setao not distinctly flattened.................... Iimbata.

FF. Modian hooks with two distinct setae; pronotur with the setae distinctly flattenod..................... hirticollis.

AA. Maxillary palpus with two segments; head and pronotum a bright coppory or orange bronze with a blue reflection; pronotum with the mosal portion of the cophalic margin extending distinctly cophalad of the cophalo-lateral

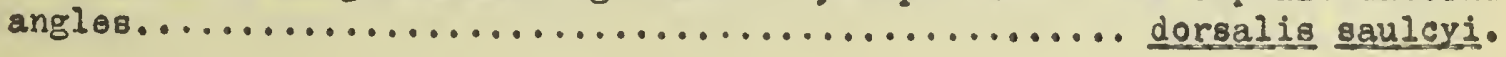



C. 6-guttata. Fab.

2908. Sholford, Journ. Linn. Soc. Lond., 2001., 30, 1908, 172-173.

Color: head and promotum dark chestnut brown or purplish brown, with a light greon or blue reflection, latoral margin of pronotum lighter in some specimens; sotao brown.

Hoad: sotao on dorsal aspoct long, slightly llattoned and prominent; diametor of ocellus 2 equal to the distance botween ocelli 1 and 2 ; fronto clygoo-labral area as broad as Long; J-shapod ridge on tho caudal part of front bearing two setae; antenna with: the first and second segments subequal in longth, the third two-thirds and the fourth onowhalf the length of the socond, the first segment with fivo or six sotae and the second with nine or ton; is maxilla with the proximal segment of the galea bearing throe setao on its mesal margin, maxillary palpus throe-segmentod; labium with, four fino sotao arm angod in a transvorse row at its ventro-distal ond, proximal segment of labial palpus with three spinowike projoctions on the ventromistal margin and with two setas on each side of these opines, the proximal segment boaring four setae and the distal segment one.

Thorax: oronotum with the cephalo-lateral anglos oxtending almost as far cophalad as the mesal portion, latoral margins slightiy carinato, primary ootao largo, prowinent, and slightly flattenod, socondary sotao small and not numorous (Fig. 58).

Abdomen: chitinized areas distinct; secondary setao short, fino and not numorous; ninth abdominal sternum with tho caudal margin boaring two grouns of four setas oach; median hooks generally with threo sotas; mosal hooks with two sotao, the spino-like projection about one-third the length of the hook (Fig. 124).

Measurements: length of larva, 20 to $24 \mathrm{~mm}$, width at the third 

abdominal segment, 2.0 to $2.5 \mathrm{~mm}$; diametor of ocellus $2, .25$ to $.28 \mathrm{~mm}$. ; distance betweon ocoll1 1 and $2, .25$ to $.28 \mathrm{~mm} ;$ length of fronto-clypoo-labral area, 1.5 to $1.7 \mathrm{~mm}$, width, 1.5 to $1.7 \mathrm{~mm}$; length of pronotum, 1.8 to $2.0 \mathrm{~mm}$. width, 2.9 to $3.2 \mathrm{~mm}$.

The larvad of this spocios can bo easily distingulshod from those of all other species by the brown setae on the head and pronotum. It is very chard acteristic in its habitat and is quito different frow most others as atad by Shelford (1908);

"This spocias does not deposit oggs in pure humus but makes use of littlo irrogularitios in clay or sand, which, contains a littlo humus and which is shadod slightly, such conditions as ars afforded by falling troes and the errozion of hill vides by small brooks. It profors a faw 10080 loaves and will lay ogge under them in proferance to other places whon they aro prosent. It does not, however, appoar to like very shady conditions. Soveral days spont in the booch and maplo forests has fallod to roveal the presence of one of these insects altho they were present in opon and partlally cleared places a short distance away whore the forest has not bocomo 6o mosopyticn.

The egge are laid in fune or early July and the majority of the larvae reach the third stage by fall. The larvas pupate the following yoar in July and the adults omorge in August. In northorn Illinois the adults rareiy appoar in autumn and it is probabls that thoy romain in tho pupal chambor until spring. There are two years botwoen genorations.

\section{C. specios $A$.}

Color: head dark purplioh brown, pronotum brown with a color pattorn of Iightor areas; setae on hoad and pronotum white, the other setae brown. 

Head: setae on dordal aspoct medium in length and prominont; diameter of ocellus 2 oqual to the distance botweon ocoll 1 and 2 ; fronto-clypoo-labral aroa 8lightly wider than long; U-shaped ridge on the caudal part of front bearing two sotae; antenna with the flrst segxent slightly shorter than the second, the third two-thirds and the fourth ono-half the length of the second, the first sogment with nine or ten sotao and the second with oight or nine; maxilla with the proximal segraent of the galea bearing throe sotae on its mesal margin, maxillary palpus throo-segmented; labium with , four line sotao arranged in a transverse row at its ventro-distal ond, proxiral segment of labial palpus with threo spine-like projections on the ventro-distal margin and with two setao on each side of these spines, the proximal segment with four sotas and the distal seguent with one.

Thorax: pronotum with the cophalo-lateral angles extending almost as far cophalad as the mosal portion, lateral margins not carinate, prinary sotao largo and prominent, sota 7 wanting, secondary setae not more than ten in numbor, and small (Fig. 59).

Abdoren: chitinized areas distinct, secondary sotao short, fow and not conspicuous (Fig. 95); ninth abdominal sternurn with the caudal margin boaring two groups of throe sotas each; modian hooks with four sotao; mosal hooks with two sotae, the spino-like projection one-third the longth of the hook (Fig.125). Measurements: longth of larva, 17 to $19 \mathrm{~mm}$, width at the third abdominal sognont, 2.4 to $2.6 \mathrm{~mm}$; d damotor of ocollus 2, 029 to $.31 \mathrm{~mm}$; distance botwoon ocol11 1 and 2, .26 to .28 om longth of fronto-clypoo-labral area, 1.10 to $1.15 \mathrm{~mm}$, width, 1.20 to $1.25 \mathrm{~mm}$; jongth of pronotum, 1.6 to $1.7 \mathrm{~mm}$, width, 2.5 to $2.7 \mathrm{~mm}$.

The larvae were collected at San Diego, California on the beach in the tide flats juet above high tide. They woro taken from sand covefod with wud 

and frow puro sand. The holos wera from ono and ono-half to throe inchos doop.

$$
\text { C. purpurea limbalis } \mathrm{K} Q \mathrm{~g} \text {. }
$$

1908 , Shelford, Journ. Linn. Soc, Lond., Zool., 30, 1908, 164m165.

Color: head and pronotum dark purplo with a groon rellection; sotao on dorsal aspoct of hoad and pronotum white, tho othor sotao brown.

Head: setse on dorsal aspect long, slightly llattened and prominent; diamoter of ocellus 2 distinctiy 2083 than the distance botweon ocolli 1 and 2; fronto-clypoo-labral area slightly wider than long; U-shapod ridgo on tho caudal part of front boaring two sotae; antenna with the first agmont sightly shorter than tho second, tho third two-thirds and the fourth ono-half the longth of tho second, the first segroent with fivo or six setas and the socond with seven or olght; maxilla with the proximal segment of the galea bearing three setao on it mosal margin, maxillary palpus throp-sogmentod; labium with. "four fino sotao arranged in a tīansverso row at tho vontro-distal ond, proximel sogment of labial palpus with thrso spino-like projoctions on its ventro-distal margin and with two sotac on each side of those spitos, proximal sogment with four sotao and the distal segment with one.

Thorax: pronotum with the cophalo-latoral anglos oxtending almost as far cophalad as tho mosal portion, lateral margins slightly carinato, primary sotao largo, prominent and slightly flattenod, secondary sotao small, not ovor ten in number (Fig. 54).

Abdomon: chitinized aroas distinct, socondary sotao short, fino, and not numerous (Fig. 96); ninth abdominal sternum with the caudal margin boaring two groups of four setas oach; median hooks with two sotas; mesal hooks with two sotas, the spino-like projoction slightly more than one-half the longth of tho hook (Fig. 126). 

Measurgiants: longth of larva, 19 to $22 \mathrm{~mm}$, width at the third abdominal segront, 1.8 to $2.2 \mathrm{~mm}$; diameter of ocellus $2, .26$ to .28 mo.; distance botwoen 0001111 and $2, .30$ to $.35 \mathrm{~mm}$; length of frontomelypoo-labtal area, 1.70 to $1.75, \mathrm{~mm}:$, width; 1.30 to $1.85 \mathrm{~mm}$; length of pronotum, 2.1 to $2.3 \mathrm{~mm}$. , vidh, 3.1 to 3.5 mors.

This subspecies is vory similar to C. purourea graminea but can be separated fron it by the larger number of secondary setae on the pronotum, and the longer longth of the spinomike projection of the mesal hooks.

The adults appoar from hibernation later in the spring than do those of C. purpurea graminea and tho oggs are laid in rJune. By fall the larvae havo reached tho second instar, in which instar thoy pass tho wintor. They appoar the latter part of the following May or the flret of June, onter the last larval instar, and pupate in July. Some of the adults appoar in Auguat while othors renain in the pupal chamber until the following spring. Thoy roach sexual maturity in the spring about a month later than does tho true purourea. Tho larvae are found in clay on ste日p banks. The burrows enter at almost a right anglo to the surface and curve into a nearly horizontal position at the inner ond. They are lrom seven to ton centimeters deep and there is usually a chimey-like structure around the oponing of the burrow which is formed frove tho soil excavatod by tho larva. Criddlo (1910) states that the larvae are found in imilar satuations at Awomo, Manitoba, tho dopth of the burrows varying from three to eight inches. The length of the larval stage " is approximstely two years and the adult stage from nine to eleven wonths. In the vicinity of Chicago, Illinois the larval stage lasts about fourteon months and the adult stage ten roonths. 

C. purpurea graminea Schpp.

1908, Shelford, Journ. Linn. Scc. I.snd., 2.001., 30, 1908, 160, 172, 173

Color: head and pronotum dark purplish bronze with a groen roflection; sotae on dorsal aspect of head and pronotum white, the other setae brown.

Head: eetae on dorsal aspect long, slightly flattened and prominent; diameter of ocellus 2 distinctly less than the distance between ocelli 1 and 2; Ironto-clypeo-labral area as long as broad; U-shaped ridgo on the caudal part of front bearing two setae; antenna with the first and secend segments cubogual In longth, the third almost two-thirds and the fourth slightly wore than ono half the length of tho second, the flrst segment with six or seven sotao and the econd with eight of nine; maxilla with the proxiral segment of the galea boaring trree setae on its mosal margin, maxillary palpus threo-agmented; labium with the four fine sotae arranged in a transverse row at the ventrom diotal ond, pooxiral segrent of labial palpus with throo spine-like projoctions on its ventro-distal margin and with two setas on each side of those spines, proxiral segment with four etae and the distal segment with one.

Thorax: pronotuw with the cephalo-lateral anglos oxtending almost as far cephalad as the mesal fortion, lateral margins olightly carinato, primary setae large, prominent and slightly llattened, secondary setae two in number, ono cephalowlaterad of setae 5 (Fig. 60).

Abdowen: chitinized areas distinct, secondary sotae not nurorous, fine and modum in length (Fig. 97); ninth abdominal stornum with the caudal margin bearing tworgroup of four setae oach; median hooks with tro setae; mesal hooks with two setae, the pine-like projection about ono-third the length of the hook (Fig. 127).

Measurements: length of larva, 19 to $22 \mathrm{~mm}$, width at the third abdominal segment, 1.8 to $2.2 \mathrm{~mm}$; diameter of ocellus $2, .26$ to $.28 \mathrm{~mm} \cdot$; 

distance botrioen ocolli 1 and $2, .33$ to $.35 \mathrm{~mm}$; length of fronto-clygoomlabral area, 1.75 to $1.85 \mathrm{~mm}$. , w1dth, 1.75 to $1.85 \mathrm{~mm}$; longth of pronotum, 2.0 to $2.3 \mathrm{rm}$, , width, 3.0 to $3.4 \mathrm{~mm}$.

The adults appear from hibernation in April, mate and lay egge the latter part of the month. Tho oggs are laid in moist,black soil. Tho larvao reach the third instar the lattor part of August or the first of Sogtember, closo their burrows and hibernate. The following spring theyfoed until about the middlo of Juno, pupate in July, and the adults appoar tho latter part of August. These hibernate and bocome sezualiy maturo the fillowing April. There àro two years botween generations.

\section{C. latosignata Lec.}

Color: head and pronotum purplish bronze with a green reflection; setae on doral aspect of head and pronotum white, the other setae brown.

Head: setae on dorsal aspect long and prominert; dianeter of ocellus 2 equal to the distanco betwoen ocelli 1 and 2 ; fronto-clygoo-labral area olightm Iy wider than long; U-shaped ridge on tho caudal part of front bearirg two setas; antonra with the first segment slightly shorter than the secend, the third two-thirds and the fourth ono-half the length of the second, the firet segment with live to seven setao and the second segment with ten to twolve; maxilla with the proximal segment of the galea boaring throo sotao on its mosal margin, maxillary palpus threemegmented; labium with, four fine setao arranged in a transverse row at the ventro-dietal ond, proximal segment of labial palpus with throe spino-like projoctions on the ventro-distal margin and with two setae on oach side of these spines, the proximal segment with fous setae and the distal segment with one.

Thorax: prorotur with tho cephalo-lateral anglos not extending as far 

cephalad as the mesal portion, lateral margins carinate, primary sota modiur in s1zo and prominent, socondary setao about thirty in number, small (Fig. 61). Abdomen: chitinized areas distinct, secondary sotae short, fine, and not nuxerous (Fig. 98); ninth abdcminal stemun with the caudal warein bearing two groups of threo setao each; redian hooke with three sotae; mosal hooks with two setae, the spine-like projection-one-third the length of the hook. (Fig. 128).

Measurements: longth of larva, 18 to 22 m., widh at the third abdw ominal segment, 2.0 to $2.3 \mathrm{~mm}$; diamotor of ocollus 2 , .2 .6 to .28 mmo; distance between ocoll1 1 and $2, .26$ to $.28 \mathrm{~mm}$; longth of fronto-clypeomlabral aro8, 1.65 to 1.75 , width, 1.75 to $1.85 \mathrm{~mm}$; longth of pronotum, 2.9 to 8.2 rem., width, 3.0 to $3.3 \mathrm{~mm}$.

The idontificatior of this spocies is not positive. The larvae wero colloctod at La Jolla, California on the beach in the tide flats just above high tide. The holes were from one and ono-half to threo inches deop and frequently curved to a nearly hordintal position at the bottow. The soil was mud or sand covered with mud.

\section{Cicindela species $B$.}

Color: head and pronotum dark purplish-bronze with a strong groen or blue roflection, lateral margins of fronotum alightly lighter in sowe spocimen setae on doreal aspect of head and pronotum white, the other setae brown.

Hoad: setao on dorsal aspect mediux in lohgth, stout and prominent; diameter of ocellus 2 equal to the distance between ocell1 1 and 2 ; frontoclypoo-labral area wider than long; U-shaped ridgo on tho caudal part of lront bearing two sotre; antenne with the first segment as long as the second, the third two-thirds and the fourth slightly loss than one-half the length of the second, the first sogment with seven to nine setae and the second with nine to 

-loven; waxilla with the proximal segment of the galoa bearing three botao on its nesal margin, maxillary palpus three-segmented; lablum with four fine sotao arranged in a transverse row at the ventro-distal ond, proxiwal sogment of the labial palpus with threo gpine-like profections on the ventrodistal margin and with two setae on each side of these pines, proximal segment with Lour setae and the distal segment with one.

Thorax: pronotum with the cophalo-lateral anglos extending almost as far cophalad as the mosal portion, the lateral margins olightly carinate, primery setac long and frominent, secondary sotae not more than twenty-11ve, minute (Fig. 62).

Abdonen: chitinized areas idistinct, secondary setae almost as long as tho primary sotae, prominent and not numerous (Fig. :9); ninth abdominal stermum with the caudal margin bearing two groups of four cotas oach; wodian hooks with two sotae; mosal hooks with two setao, the spino-like projection onethird the length of the hook (Fit. 129).

The larvae wero collected at Alamosa, Colorado on the banks of the Rio Grande River, in dark, coarse sand on level and sloping land which was always moist. The burrows were from two to four inches doep, usually sloping, the direction varying with the kind of 8011.

\section{C. roganda Doj.}

1878, Horm, Trans. Amer, Ento. Soc., 7, 1878, 35-37, pl. 2, I1g8. 4a to b. 1908. Sholford, Journ.Linn. Soc. Iond., Z0010,30, 1908, 170.-.

Color: hoad and pronotum dark epppory bronzo with a light groen rollection; sotac on dorsal aspect of hoad and pronotur white, tho other seta brown Head: sotae on dorsal aspoct long, stout, and prominent; diamoter os 

ocellus 2 equal to the distance botween ocelli 1 and 2 ; fronto-clypoo-labral aroa wider than long; U-shaped ridgo on the caudal part of the front boarirg two sotae; antenna with the first and second sogments oubequal in length, tho third three-fourths and the fourth one-half the length of the second, the firgt segront with nine or ten etae and the second with soven or eight; maxilla with the proximal segment of the galea bearing three setae on its mesal margin, maxillary palpus threesegmentod; labium with "four fino sotao arranged in a transverse row at its ventro-dtetal ond, proximal segment of labial palpus with thros gine-1ike projections on the ventro-distal margin and with two hooks on oach side of these spines, the oroximal segment with four setae and the distal segment with one.

Thorax: pronotum with the cephalo-lateral anglee oxtending almost as far cephalad as the mesal portion, lateral margins carinate, primary setae mediure in size and prominent, socondary sotao.gmil and not nurerous (Fig. 63). Abdomen: chitirized areas distinct, secondary sotae very short, small, and not numeroue (Fig. 100); ninth abdominal stornuro with tho caudal wargin boaring two groups of four sotae each; modian hooks with ono sota, if two aro prosent, one is much smaller than the other; mesal hooks with two setae, tho spine-1ike projection about one-sixth the longth of the hook (Fig. 130).

Measuromente: length of larva, 16 to $18 \mathrm{~mm}$, width at the third abdes ominal segment, 2.0 to $2.2 \mathrm{mon}$; diameter of ocellus $2, .2 .6$ to $.28 \mathrm{~mm}$; distance botween ocelli 1 and $2, .26$ to .28 mm; lencth of fronto-clypoom labral area, 1.50 to $1.60 \mathrm{~mm}$, width, 1.60 to $1.70 \mathrm{~mm}$; lengtb of pronotux, 1.7 to 1.8 mm., width, 2.7 to $3.0 \mathrm{~mm}$.

The larvae of this gyocies aro more goneral in their habitat than some of the other spocies of Cicindela. The have boon collocted from wet sandy soll, wot mudy soll, molst clay, and soil with considerable humus. In genoral, 

howover, thoybaro found in sandy situations around the margins of small ponds, lakes, and streams which have too much decaying vegetable mattor for $\mathrm{C}$. hirtico1118. The burrors aro about ten centinotors deop and their general direction is at right anglos to a sloping surface and oblique to a horizontal surface. the oggs are laid in Way and June and the larvae reach the third instar by fall, in which instar they pass tho winter. The adulto omerge tho following sumer, hibernate, and appear in fay of the sefond year, roach sexual maturity, lay their eggs and die. Tho. 1ifo-history requires two years.

\section{Iopida Doj.}

1908, Sholford, Journ. Iinn. Soc. Lond., Z001., 30, 1908, 172. .

Color: hoad and pronotum bronze with a groenish-blue roflection; setae on corsal aspect of hoad and pronotum tranoparent or glassy, tho other sotao brown.

Head: sotae on dorsal aspect long, slonder, and grominent; diameter of ocellus 2 distinctly greater than the distance betweon ocoll1 1 and 2 ; 1rontclypoo-labral area slightly broader than long; U-shayed ridge on tho caudal part of the front with two setae; antenne with the first segment subequal in length to the second, the third slightly more than ono-half and the fourth onofourth the length of the second, the first segment with six or seven setae and the second with nine or ten; maxilla with the proximal segment of the galea bearing three sdtae on its mesal margin, naxillary palpus three-segmented; labium with four fine setae arranged in a transverse row at the ventrom distal ond, proximal sogment of labial palpus with two spino-like projoctions on the ventrond stal margin and with two setae on each side of these spines, the proximal segnent with four setae and the distal segment with one.

Thorax: pronotum with the mosal portion extending distinctly cephalad 

of the cophalo-lateral angles, lateral margins not carinato, primary sotao not largo or frominent, secondary sotae scall and numerous (Fig. 64).

Abdomon: chitinizod areas distinct, seccndary setao about ono-third tho length of the primary setae, fine and not numerous (FIg. 101); ninth abdominal oternum with the caudal margin bearing two groups of throe sotao each; median hooks with two sotao; mosal hooks with two setae, tho spine-like projection one-sixth the length of the hook (Fig. 131).

Measurements: length of larva, 14 to $16 \mathrm{~mm}$, width at the third abdominal segment, 2.0 to $2.2 \mathrm{~mm}$; dameter of ocellus 2 , .32 to $.24 \mathrm{~mm}$; diatance between ocel11 1 and $2, .20$ to .222 ; length of fronto-clypoo-labral area, 1.45 to $1.55 \mathrm{~mm}$, Width, 1.60 to $1.70 \mathrm{~mm}$; length of pronotum, 1.60 to $1.70 \mathrm{~mm}$. width, 2.5 t० $2.7 \mathrm{~mm}$.

The life-history of this species, as given by shelford (1908) for the northern part of Illinols, differs from that of all others which he had observod, in that the larval stage lasts almost two yoars and the adult stage but a month or slightly more. The eggs aro laid the latter part of July and the second instar is roachod by autum. They pass tho winter in this instar, food the noxt spring and summer and reach the hitd inotar in June or July. They foed until lato fall, hibernate, and come out about the firet of the following May. The larvae pupate in June or July, and the adults soon emergo, lay oggs, and die. The spocios is two-brooded, adult from oach brood appearing in alternate years. As a result in May, both second and third stago larva can bo socurod, in July, adults, eggs, first and third stago larva, and in October, second and third otage larvae. Tho following table gives tho lifohistory and the etages present for the three most important monthe of the year; 

TableI.

The Iffo-History of Cicindela ropanda*.

\begin{tabular}{c|c|c|c|c|c|c}
\hline & \multicolumn{2}{|c|}{ 1st. year } & \multicolumn{2}{c}{ 2nd. yoar } \\
\hline Brood No. & May & July & Oct. & May & July & Oct. \\
\hline I & 3 & $A-E-1$ & 2 & 2 & 3 & 3 \\
\hline II & 2 & 3 & 3 & 3 & $A-E-1$ & 2 \\
\hline
\end{tabular}

Criddlo (1910) states that the lifo-bistory of C. repanda is probably the same at Aweme, Manitoba as at Chicago, Illinois, 1.e., the larval stage lasts approximately twenty-two months and the adult stage two months.

The eggs aro laid and the larva live in sand which is slightly shifting. The burrows are from 25 to 37 inches deop in northern III inois, and from 58 to 72 inches deep at Aweme, Manitoba.

\section{C. gratiosa Guer.}

Color: head and pronotum dark purplo with a blue reflection, setae on dorsal aspoct of head and pronotum transparent or glassy, tho othor sotae brown.

Head: setae on dorsal aspoct long, slonder, and not conspicuous; diamen etor of ocellus 2 dirtinctiy greater than the distanco between ocelli 1 and 2; fronta-clypeo-labral area as long as broad; U-shapod ridgo on the caudal part of front boaring two setae; antonna with the first sogment subequal in longth to the second, the third slightly more than one-half and the fourth ono-foueth the length of the second, the firet segment with soven or oight setae and the second with ten or eleven; maxilla with the proxiwal segment of the galea

* $A=$ adult, $E=\operatorname{cgg}, 1=1$ st. instar, $2=2$ nd. instar, and $3=3$ rd. instar. 

bearing three sotac on its mosal margin, maxillary palfus throo-segmentod;

labium with four fino sotao arranged in a tranoverse row at its ventrodistal ond, proximal ogment of labial palpus with throe spino-like projections on the ventrodistal margin and with two sotae on oach side of theso spinos, the proximal segment with four setae and the distal segment with one;

Thorax: pronotum with the mesal portion extending distinctly cephalad of the cophalo-lateral angles, latoral margins carinate, primary sotae small and inconspicuous, secondary setae minute and numerous (Fig. 65).

Abdomen: chitinized areas on abdomen indistinct, secondary setae short fino and numerous (Fig. 102); ninth abdominal stornum with the caudal margin boaring two group of three setae each; median hooks with threo setae; mesal hooks with two sotae, tho spine-like projection about one-eixth the length of the hook (Fig. 132).

Measuroments: length of larva, 17 to $19 \mathrm{~mm}$, width at the third abdominal segment, 2.0 to $2.2 \mathrm{~mm}$. ; diameter of ocellus $2, .30$ to $.33 \mathrm{~mm}$. ; distance between ocelli 1 and $2, .17$ to .18 m.; length of frontonclyped-labral area, 1.35 to $1.40 \mathrm{~mm}$, width, 1.35 to $1.40 \mathrm{~mm}$; length of pronotum, 1.5 to $1.7 \mathrm{~mm}$, width, 2.3 to $2.5 \mathrm{~mm}$.

The larva of this species wore collected at Mobile, Alabama, in what was probably an artificial clearing. Tho soil was sandy and had sufficient clay in it to make it mold weli. The larval burrows wore vertical and from 22 to 44 inches doep.

$$
\text { C. tranquebarica Herb. }
$$

1908, Shelford, Journ.Linn. Soc. Lond., Z0010, 30, 1908, $172 .$.

Color: head and pronotum dark purplo or purplish-bronzo with a strong 

groon reflection; setae on dorsal aspect of hoad and pronotum whito, the other sotac brown.

Hoad: sotao on dorsal aspoct modium in length and prominent; dianoter of ocollue 2 sightly greater than the distanco botwoen ocelli 1 and 2; frontom clypoomlabral area elightly wider than long; U-ehaped ridge on tho caudal part of the front bosing two setao; antenna with tho first and second segments oqual in longth, the third two-thirds and the fourth ono-half tho length of tho second, the firet segment with seven or eight setae and the second with nine or ten; maxilla with the proximal segmont of the galoa bearing throe setao on its mosal margin, maxiliary palpus throe-segmented; labium with four fine setao arranged in a transverso row at the ventro-diotal ond, proximal segment of labial palpus with throe spino-like projections on the vontro-distal margin and with two setae on each side of these spines, the proximal segment with four sotac and the distal segrent with one.

Thorax: pronotum with the cophala lateral anglos extending alnost as far coghalad as the mosal portion, tho lateral margins slightiy carinate, primary setae large and prominent, socondary setae emall and not over twontyfive in number (Fig. 66).

Abdomen: chitinized areas distinct, socondary setas frow ono-half to almost as long as the primary setae, prominent and not nunerous (Fig. 103); ninth abdominal sternum with the caudal margin bearing two groups of four sotae each; median hooks with throe getae; mesal hooks with two setae, the spinolike projection one-third the length of the hook (Fig. 133).

Measurements: longth of larva, 21 to 24.mm., width at the third abdm ominal segment, 2.4 to $2.8 \mathrm{~mm}$; diameter of ocellus 2, .29 to .31 mm.; distance between orelli 1 and $2, .26$ to $.27 \mathrm{~mm}$; longth of fronto-clyped-labral area, 1.80 to $1.90 \mathrm{~mm}$, width, 1.90 to $2.00 \mathrm{~mm}$; length of pronotum, 2.1 to 2.3 mm., width, 3.3 to $3.8 \mathrm{~mm}$. 

The 11fe-history of this spocies is essentially tho same as that of C. purourea grominea. Tho eggs aro laid in a varioty of moist situations but are moro ofton laid in sandy soil with some hurous and in among some rogetation. The burrows are straight and from nine to twenty inches deop. At Brandon, Manitoba the larvae wero found at a uniform dopth of about ighteen to twexty. inches and wore generally dug from sandy soil. Criddle (1910) says "Two distinct sizes wore found among the larva in autumn, which correoponded to the first and second year of venusta, so that it seems highly ptobable that the larval Iife lasts two years, while that of the adult continues for about eleven months".

C. oregona Lec.

Color: head and pronotum datk coppery bronzo with a very strong blue roflection; latoral margin of pronotum lighter in somo specimons; setao on dorsal aspect of head and pronotum white, the other setae brown.

Head: setae on dorsal aspect slender, of modium length and not conspicuous; diameter of ocellus 2 equal to the distance between ocolli 1 and 2; fronto-clypoo-labral area slightly wider than long; U-ahaped ridge on the caudal part of the front bearing two sotae; antenna with the first oogment slightly shorter then the second, the third two-thirds and the fourth one-half the longth of the second, the first segment with nine to elover setao and the second oegment with nino to eleven; maxilla with tho proximal segment of tho galoa bearing throe setae on its mesal margin, maxillary palfus threo-segmented; labium with four fine setae arranged in a transverse row at its ventrodistal ond, proximal segment of labial palpus with throe spino-like projections on the ventro-distal margin and with two setae on each side of these spines, the proximal segment with four setae and the distal segment with ono. 

Thorax: pronotum with the cophalo-lateral angles extending almost as far cephalad as tho mesal portion, latoral margino carinate, primary votao not large of prominent, secondary sotae short, about twenty-five or thirty in number and with a row on each side of the meson (Fig. 67).

Abdomen: chitinized areas distinct, secondary sotae about ono-fourth the length of the primary setae, fine and not nunerous (Fig. 104); ninth abdominal sternum with the caudal margin boaring two groups of three sotac oach; modian hooks with threo setar; mesal hooks with two setao, the spine-like projection about one-third the longth of the hook (Fig. 134).

Measurements: length of larva, 19 to $22 \mathrm{~mm}$, width at the third abdominal segment, 2.3 to 2.5 ma.; diameter of ocellus $2, .26$ to .28 mm.; distance botwoen ocelli 1 and $2, .26$ to $.28 \mathrm{~mm}$; length of fronto-clypeo-labral area, 1.60 to 1.70 ; widh, 1.70 to $1.80 \mathrm{~mm}$; length of pronotum, 1.80 to 2.00 midth, 3.0 to $3.3 \mathrm{mon}$

This spocies is similar to C. 12-guttata but can bo distinguishod from it by the larger number of setas on the pronotura, and the blue reflection, which is much stronger. The larvas were collected in New Moxico, Colorado, and California. Those colloctod in New Moxico wero taken from moist clayey soil with some humus mixod in it. Tho holes vero about fivo inchos in depth and entered on a sters, sloping bank and ourvod to a vertical position at the bottom. Those colloctod in Colorado Wors dug from alluvial soil along the bank of a river, which had boen deposited by high water. In California tho larva wero collocted by Dr. F. E. Blaisdell Jr. in sand.

$$
\text { C. 12-guttata Doj. }
$$

1908. Shelford, - Journ. Iinn. Soc. Iond., Z001., 30, 1908, 172 - 173. 

Color: hoad and pronotum coppery-bronzo with a groon.rofloction, lateral margins of pronotum slightly lighter in some spocimons; gotao on dorsa aspoct of head and pronotum white, the other setae brown.

Head: sotas on dorsal aspoct, long, stout, and prominent; diactor of ocollus 2 slightly 108 s than tho distance botwoon ocelli 1 and 2 ; frontociypo-1abral aroa widor than long; U-shaped ridgo on tho caudal part of front bearing two sotao; antenna with the flrst segment silghtly shorter than the second, the third two-thirds and the fourth ono-half the longth of the second; the first segment with nins to eloven ortao and tho second with nine to elovon; maxilla with the proximal aegment of the galea bearing throe sotac on 1 ts mesal margin, waxilary palpus thres-sggmented; labiur with four fino setao arranged in a transvorso row at its ventro-distal ond, oroxinal segment of fabial palpus with three spino-like projections on the vontro-distal margin and with two setas on each side of those spines, the proxinal segrent with four sotas and the distal sogment with one.

Thorax: pronotum with tho cophalo-latoral angles oxtending as far cophalad as the mesal portion, lateral margins slightly carinato, prinary setao modium is size and prominent, secondary setas minute, not woro than ten in number and not with a row on each side of the meson (Fig, 68).

Abdomen: chitinizod arsas distinct, secondary sotao about ono-third the longth of the primary sotar, fino and not numerous (Fig. 105); ninth abdorninal sternum with the caudal margin boaring two groups of throo sotao each; median hooks with throe sotao; mosal hooks with two sotao, the spine-like projection one-third the length of the hook (Fig. 135).

Measurements: length of larva, 18 to $20 \mathrm{~mm}$, width at tho third abdominal segrent, 2.2 to $2.4 \mathrm{~mm}$; diameter of ocellus 2 , .26 to .25 mm•; distance botwosn ocoll1 1 and $2, .39$ to $.30 \mathrm{~mm}$; length of ironto-clypoo-labral arsa, 1.50 to $1.70 \mathrm{~mm}$, width, 1.70 to $1.80 \mathrm{~mm}$; length of pronotum, 1.90 to 2.10 

mon., width, 3.0 t, $3.3 \mathrm{~mm}$.

The Ilfo-history of this spocios has not boen dotorminod dofinitoly but liold obsergations would sosm to indicato that it is similar to C. rgoanda. The larvae are usually found in clay or hursus. Criddle (1907) found the larras burrowing in large numbers along the banks of a river at Awome, Manitoba, in clayoy, raddy, and sandy soil. In the sumarer time the burrows aro from four to fivo inchos in dopth and in tho wintor time from six to fifteon inchos. Tho holes generally slant obliquely into the bank.

\section{Functulata Fab.}

1908. Shelford, - Journ. Linn. Soc. Lond., Zoob., 30, 1908, 172.. .

Color: head and pronotum purplish bronzo with a faint bluo roflection; setae on dorsal aspect of head and pronotum white, the other setae brown.

Head: sotao on dorsal aspoct modium in length and prominent; diameter of ocsllus 2 slightly less than the distance between ocelli 1 and 2 ; frontom clypoo-1abral area as long as broad; O-shapod ridgo on the caudal part of Iront boaring two sotao; antenna with the first and socond segments subequal in length, the third slightly shorter than tho socond and the fourth about onohalf its longth, the first sogment with five ot six sotao and the socond with nine or ton; maxilla with the proximal sogment of the galea bearing throe setao on 1ts mesal margin, maxillary palpus threo-agmentod; Isbium with the four fine sotae at the vontro-distal end arranged in a transverse row, proximal sogment of labial palpus with throe spite-like projections on its ventro-distal margin and with two setae on each side of these spines, proximal segment bear ing lour sotas and the distal sogment one.

Thorax: pronotum with the ephalo-latoral angles oxtonding almost as 

far cophalad as tho uesal portion, latoral margins slightly carinato, primary sotao 5 and 6 small, secondary setao small and not numerous (Fig. 69).

Abdomon: chitinized areas indistinct, secondary sotao not nurerous and about one-half the length of the primary setae (Fig. 106); ninth abdominal eternum with the caudal margin boaring two groups of throe sotao each; modian hooks with throo sotao; mesal hooks with two sotae, tho spino-like projection on-third the length of the hook (Fig. 136).

Measuroments: length of larva, 14 to $16 \mathrm{~mm}$, width at the third abdominal segment, 1.8 to $2.0 \mathrm{~mm}$; dianeter of ocslus $2, .20$ to $.23 \mathrm{~mm} \cdot$; distance betwesn ocelli 1 and $2, .23$ to .25 mm.; longth of ironto-elgpoo-labral area, 1.3 to $1.4 \mathrm{~mm}$, width, 1.3 to $1.4 \mathrm{~mm}$; longth of pronotum, 1.5 to $1.7 \mathrm{~mm} .$, width, 2.3 to $2.7 \mathrm{~mm}$.

The Iife-history of this specios as given by Shelford (1909) diffors frore that of other specios in that tho adults do not hibermate and there is only a single year reguired for the life-history. The oggs aro laid in rolativoly hard, dry soil, usually humus, the latter part of July. Tho majority of the larvao aro in the third instar by Septombor, in which instar thoy hibornato and appear early the noxt spring. They food until April or early June when they pupato. The adults omerge in early July, mate, lay oggs and dic. Tho larval burroms during the fooding soason are from thirty to fourty contimetors deop but aro slightly shellowor in the suramer just bofore the larvao go into the pupal stage. Criddle (1907) states that the larvas aro found at Areme, Manitoba in small mossy place betweon clumps of grass in dry situations: Tho depth of the holes ranging from 18 to 26 inches. The adults do not hibemato and it is probable that the larval stage lasts over two wintore. 

C. flavopunctata roctilatera. Chd.

Color: head and pronotum purplo or purplish-bronze with a bluo rollection; setas on dorsal aspect of hoad and pronotum whito, the other sotae brown.

Head: setac on dorsal aspect long and prominent; diameter of ocellus 2 greater than the distance betwoen ocolli 1 and 2; fronto-clypeo-labral area as long as broad; U-shapod ridge on the caudal part of front bearing two sotao; antenna with the first segment slightly shorter than the second, the thira a Iittle more than one-half and the fourth a little more than one-third the length of the second, the first segment with five or six setae and the second with nine or ten; maxilla with the proxival sogment of the galea beating throe sotas on its mesal margin, maxillary palpus three-segmented; laboum with : four fino setae arranged in a transvorse row at its ventro-distal ond; proximal sogment of labial palpus with throe spino-like projections on tbo vontromistal margin and with two setae on each side of these spines, the proxinal segment with four sotal and the distal sogment with one.

Thorax: pronotum with tho cophalo-fateral angles extending as far cophalad as the meeal portion, latoral margins carinate, primary sota largo and proninont, secondary sotao small and not numerous (Fig. 70).

Abdomon: chitinizod areas distinct, secondary seta almost as long as the primary sotao, lino and not numorous (Fig. 107); ninth abdorinal sternum with the caudal margin boaring two groups of thres sotao oach; median hooks with throo setae; mesal hooks with two sotao, the opine-like projection onothird the longth of the hook (Fig. 137).

Measurements: length of larva, 17 to $19 \mathrm{~mm}$, width at the third abdominal segment, 2.0 to $2.3 \mathrm{~mm}$; diamoter of ocollus $2, .26$ to $.27 \mathrm{~mm}$. ; distance botweon ocoll 1 and $2, .23$ to $.25 \mathrm{~mm}$; length of fronto-clypoomlabral aroa, 

1.25 to $1.35 \mathrm{~mm}$, width, 1.25 to $1.35 \mathrm{~mm}$; longth of pronotum, 1.7 to $1.3 \mathrm{~mm}$;, wiath, 2.7 to $2.9 \mathrm{~mm}$.

Tho larvae woro collectsd at Houston, Toxas in heavy, clayoy soll. Tho holes wers about four inchos long and curved to an almost horizontal position at the bottom.

\section{C. unipunctata Fab.}

Color: hoad and pronotum purgilish-bronze with a grosn roflection; setas on dorsal aspoct of head and pronotum transparent or glassy, the other setas brown.

Head: setae on dorsal aspect long, etout and prowinent; diameter of ocollus 2 slightly less than the distanco botwoen ocelli 1 and 2 ; frontoclypoo-labral aroa as long as broad; U-shand ridge on the caudal part of front boaring two setae; antenna with the first segment as long as the second, the third two-thirds and the fourth one-half the length of the second, the first Begment with seven or eight setae, and the second with seven or eight; maxilla With the proximal segment of the galea bearing throe setae on its mosal margin, maxillary palpus thres-segmentod; labium with $\rightarrow$ four fine sotae arranged in a transverse row at its ventro-distal ond, proximal segment of labial palpus with throe spino-like projections on the ventro-distal margin and with two setao on each oide of these spines, the proxiral sogment with four sotas and the distal segment with one.

Thorax: pronotum with tho cophalo-lateral anglos extonding distinctly cophalad of the mosal portion, lateral margin carinate, primary sotao not large or conspicuous, socondary setae wanting or vory mituts (Fig. 71).

Abdomen: chitinized areas distinct, secondary sotas bot numorous and irom hort to slightly more than one-hall the length of the orimary sotae 

(Fig. 108); ninth abdominal stemum with tho caudal margin bearing two groups of four setao each; median hooks with thres setas; mesal hooks with fivo or oix sotao, tho spino-like projoction about ono-thirs tho longth of the hook (Fig. 138).

Measuromonts: Iongth of larva, 22 to $25 \mathrm{~mm}$, width at the third abdominal segment, 3.0 to $3.3 \mathrm{~mm}$; diametor of ocollus $2, .38$ to $.30 \mathrm{~mm}$; distance botwoon ocolli 1 and $2, .31$ to $.33 \mathrm{~mm}$; length of fronto-clypeo-labral area, 1.9 to $2.0 \mathrm{~mm}$, width, 1.9 to $2.0 \mathrm{~mm}$; longth of gronotum, 2.1 to 2.3 mm., width, 3.5 to $3.8 \mathrm{~mm}$.

This spocios is easily soparated from all others by the position of the cophalo-lateral angles of the pronotum, which oxtend distinctly cephalad of the mesal portion. The larvas wero dug at La Fallotte, Tonnesaoe in baro, rocky soil. The burrows wero porpondicular for the flrst threo or four inches and then curved to a horizontal position.

\section{C. abdominalis Fab.}

Colot: head and pronotum dark purplish-bronze with a green or blue reflection; setae on dorsal aspect of head and pronotum transparent or glassy, the other sotae brown.

Head: setas on dorsal aspect, long, slender and not prominent; diameter of ocollus 2 distinctly groater than tho diatanco botwoon ocolli 1 and 2; fronto-clypoo-labral aroa as long as broad; U-shaped ridge on the caudal 1. part of the front boaring throe sotao; antenna with the first segment slightly shortor than the second, the third onomalf and the fourth one-fourth tho length of the second, the first segment with seven or eight setae and the gocond with ton tontwolve; maxilla with the proximal segment of the galoa bearing throe sotae on its mosal margin, maxillary palpue throo-segmented; 

labium with four fine sotae not arranged in a transverso row at its ventrodistal ond, the two mesal sotao caudad of the latoral ones, proximal cogrent of the labial palpus with throe spine-like projections on the ventro-distal margin and with two sotao on each side of those opines, the proximal segment with four sotas and the distal segment with one.

Thorax: pronotum with tho wosal portion extending distinctly cophalad of the cephalo-lateral angles, lateral margins slightly carinate, prinery sotao long, slonder and inconspicuous, socondary sotao short and fairly num orous (Fig. 72).

Abdomen: chitinize aroas indistinct, socondary sotao short, fine and numerous and occuring botween as woll as on the chitinized areas (Fig. 109) ninth abdominal stomum with tho caudal margin bearing two groups of throo sotar each; modian hooks with throe setas; mosal hooks with throo sotae, the opine-like projection wanting or inconspicuous (Fig. 139).

Moasuroment 3: length of larva, 18 to $20 \mathrm{~mm}$, width at tho third abdominal segment, 2.0 to $2.3 \mathrm{~mm}$; diametor of ocellus 2 , .29 to .31 m.; distance botwoon ocelli 1 and 2 , .29 to.21 mo; longth of fronto-clypeo-labral.area, 1.65 to $1.75 \mathrm{~m}$. , widh, 1.55 to $1.75 \mathrm{~mm}$; length of pronotum, 1.9 to $2.1 \mathrm{~mm}$. , widh, $2: 3$ to $2.5 \mathrm{~mm}$.

The larvas wero collectod at Southern Pinos, North Carolina by Mr. A. H. Yano in hard soil at the side of a road. The burroms wero small and about twonty-five inches doen. Tho identification of this spocies is not cortain.

$$
\text { C. marginata Fab. }
$$

Color: hoad and oronotum dark purplish-bronze with a atrong blue reflection; sotae on dorsal aspect of hoad and pronotum transparent or glassy, 

the other sotas brown.

Hoad: sotae on dorsal aspoct long, slonder, and inconspicuous; diamoter of ocellus 2 distinctiy groater than the distanco botweon ocolli 1 and 2 ; fronto-clypoo-labral area as long as broad; U-shapod ridgo on the caudal part of front boaring two setae; antenna with the first segiont suboqual in longth to the second, the third two-thirds and the fourth slightly loss than ono-half the length of the second, the first segmont with nine or ten setae and the second with nine or ten; maxilla with the proximal segment of the galea bearing threo sotas on its mosal margin, maxillary palpus throe segmented; labium with four ino setas arranged in a transvorso row at ita vontro-distal ond, the proximal egment of the labial palpus with throo opino-like projections on the ventro-distal margin and with two sotao on each sido of those spines, tho proximal segment with four sotae and the distal segment with one.

Thorax: pronotum with the cophalo-latoral anglos not oxtending as far cophalad as tho mosal portion, tho latoral margins slightly carinato, primary sotae not largo or conspicuous, secondary sotas small and not numerous (Fig. 73)

Abdomen: chitinized areas distinct, secondary setae short, fine and numerous (FIg. 110); ninth abdominal sternure with the caudal margin bearing two groups of thros setao each; modian hooks with throo sotas; mesal hooks with nine or ton setao, the spino-like projection almost obsolete (Fig. 140 ).

Measuromonts: longth of larva, 19 to $22 \mathrm{~mm}$, width at tho third abdomm inal segment, 2.2 to $2.4 \mathrm{~mm}$; diameter of ocellus $2, .33$ to $.35 \mathrm{~mm}$; distance botwoon ocoll1 $I$ and $2, .28$ ito $.30 \mathrm{~mm}$; longth of fronto-ciypoo-labral area, 1.55 to $1.55 \mathrm{~mm}$. , width, 1.55 to $1.55 \mathrm{mam}$. ; length of pronotum, 1.7 to $1.9 \mathrm{~mm}$, , width, 2.8 to $3.0 \mathrm{~mm}$.

This spocies is oasily distinguishod by the large number of sotas on the mesal hooxs. The larva more collected at Galveston, Toxas on Donver 

Beach, a short distanco back from the shore line in sandy soll with scattorod vegotation, the larva occuring in the opon places. The holos wero from nino to ten inches doep.

\section{C. formosa Say.}

Color: head and pronoture chestnut-brown with a color pattorn of lightor areas; setae on dorsal aspect of head and pronotum transparent to white, the other setae brown.

Head: sotas on dorsal aspect long, stout, and prominent; diameter of ocellus 2 distinctly less than tho distanco betwoen ocelli 1 and 2 ; frontoclypoo-labral arsa as long as broad; U-shapod ridge on the caudal part of lront boaring throe setae; antenna with the first segront slightly shorter than the second, the third ono-half and the fourth one-lourth the length of the second, the first segment with fivo or 8 ix setae and the second with nine or ten; waxila with the proximal segment of the galoa bearing four setae on the mesal margin, maxillary palpus threo-eegmented; labiurn with . four fino setae arranged in a transvorse row at the ventrodistal ond, proximal segment of labjal palpus with two spino-like projoctions on tho ventro-distal margin and with three sotao on the mosal side and two on the lateral side of these spines, proximal segment with five sotas and the distal sogrent with one.

Thorax: pronotum with the cephalo-lateral angles extending almost as far cophalad as the mesal portion, lateral margins carinate, primery sotao not large or prominent, setae 5 and 6 wanting, socondary setae wanting (Fig. 74).

Abdomen: chltinized arsas distinct, setondary sotae about one-half the langth of the primary sotas, fine and not numerous (Fig. 111); ninth abdominal stornum with tho caudal margin boaring two groups of four sotao oach; modian hookg with two sotae; mesal hooks with four sotao, the spino-like projection 

ono-third the longth of the hook (Fig. 141).

Moasurements: length of larva, 24 to $26 \mathrm{~mm}$, width at the third abdouinal segmont, 3.4 to $3.6 \mathrm{~mm}$; diameter of ocollus $2, .33$ to .34 mm.; distance botween ocoll1 1 and $2, .39$ to $.40 \mathrm{~mm}$; length of fronto-clypoo-labral area, 2.5 to $2.5 \mathrm{~mm}$., width, 2.5 to $2.6 \mathrm{~mm}$; length of pronotum, 2.9 to $3.0 \mathrm{~mm}$, width, 4.2 to $4.5 \mathrm{~mm}$.

The larvae were collected at Sedalia, Colorado in a sand duno near the Rio Grande rivor. The sand was ccarso and fino mixed and had probably boen deposited by high water. The holes were vertical and about twenty-two inches deop. The burrows have a pit similar to that of $\underline{C}$. formesa generoga.

\section{C. formosa generosa Dej.}

1908. Shelford, Journ. Linn. Soc. Lond., Z001., 30, 1908, 172.

Color: head and pronotum chostnut-brown with a color pattern of lighter areas; sotao on dorsal aspect of head and pronotum transparent to ihito, the other setae brown.

Head: setae on dorsal aspect long, stout, and prominent; diameter of ocollus 2 distinctly less than the distanco between ocelli 1 and 2; frontoclypoo-labral area as long as broad; U-shapod ridge on the caudal part of front bearing thros setas; antenna with the first segment glightly shorter than the second, the third one-half and the fourth one-third the length of the second, the first segment with six or sevon setae and tho second with nino or ton; maxilla with the proximal segment of the galea bearing four setae on its wesal margin, maxillary palpus threo-segrentod; labium with. . four fino sotao arranged in a transverse row at its ventro-distan end, proximal segment of the labial galpus with two spino-like projections on the vontro-distal margin and 

with throe setao on the wosal side and two on the lateral side of these spinos, the proximal segment with fleo setae and the distal segront with ono.

Thorax: pronotum with the cephalo-lateral anglos not extending as far cophalad as the mosal portion, the lateral margins slightly carinate, prinary sotas not largo and prominent, seta 6 wanting, secondary setao wanting (Fig. 5I) Abdomon: chitinizod aroas distinct, socondary setao almost as long as the primary setao, slender and numerous (Fig. 90); ninth abdominal sternum with the caudal margin bearing two groups of four sotae each; median hooks with throo setae; mosal hooks ith four setae, the spine-like projection ono-third the longth of the hook (Fig. 142).

Moasurgments: length of larva, 22 to $24 \mathrm{~mm}$, width at the third abde orsinal segment, 3.0 to $3.3 \mathrm{~mm}$; diameter of ocellus $2, .30$ to $.32 \mathrm{~mm}$. ; distance between ocoll1 1 and $2, .37$ to $.40 \mathrm{~mm}$.: length of fronto-clypoo-labral area, 2.2 to $2.4 \mathrm{~mm}$, width, 2.2 to $2.4 \mathrm{~mm}$; length of pronotum, 2.4 to $2.7 \mathrm{~mm}$. width, 3.5 to $4.2 \mathrm{~mm}$.

The larvao of this subspocios aro similar to those of C. formosa but can be distinguishod from thom by the smaller average width of the pronotum and the prosence of three setas on the modian hooks.

The adults orergo from hibernation in April or Hay and lay egga in May or June in sandy soil which is slightly shifting. Tho eggs hatch in June and the larvae reach the third instar by the lattor part of August or the first of September. They cloos thoir burrows tho lattor part of september or the first of October and go into hibernation, appearing again in thé spring. Pupation takes place in June or July and sore of the adults omergo frow the pupal chamber during the summer while the romainder stay in the pupal chamber until the following spring. Tho adults appoar in April or May, bocome sexually maturo in about a month, lay eggs, and dio. 

Tho larvae of this spocios aro vory poticablo bocauso of thoir poculiar burrows. The main part of the burrow is from twelvo to twonty inches doep and vortical thruout tho groator part of its courso. About two-thirds of an inch from the top the burrow corves sharply to a horizontal fosition and opons into a small pit. This construction serves to koop the sand, which is always slightly shifting, from filling up the burrow and also serves as a trap for catching insects. The larva cemonts the sand imrodiately around the opening with salive. which loep it fron caving in. The pupal chamber is an oliçu side cavity about four irches below the durface. The upper fart and much of the lower part of tho burrow is fillod with sandwhich is taken fror this cavity.

\section{C. ecutellaris lecontol Hald.}

1908, Shelford, Journ. Iinn. Sec. Lond, 2001., 30, 1908, $172 .=$

Color: hoad and gronotum purplishobrorzo with a groen roflection; sota on the dorsal aspect of head and pronotum white, the other setae brown.

Head: setee or dorsal aspect long, stout, and prominent; dianeter of ocellus 2 equal to tho distance betioen ocelli 1 and 2 ; fronto-clygeo-labral area as long as broad; U-shaped ridge on the caudal part of the front boaring throe sotae; antenna with the first segment suboqual in length to the seccnd, the third two-thirds and the fourth onewhalf the length of the secord, the first gegment with five or six setae and the second with ten to twelve; maxilla with the proximal segment of the galea bearing three setae on its mesal nargin, maxillary palpus three segmented; labium with; four fino setao arrarged in a transverse row at the ventro-distal end, proximal segment of labial palpus with three epire-like projections on the ventro-distal margin and with two setae on each side of these spines, the proximal segment with four setae and the distal segment with one. 

Thorax: pronotun with the cephalo-lateral anglos oxterding almost as far cophalad as the mesal portion, latoral margins carinate, primary setao largo and prominent, secondary sotae small, not more than fifty in number, and with

a row on each side of the meson (Fig. 75).

Abdower: chitinized areas distinct, most of the secondars sotac short, fine and numerous (Fig. 112); nintr abdoninal sternum with the caudal margir bearing two grours of four setao oach; median hooks with throe sotae; mogal hooks usually with four setae but ocassionally with three, the spine-like prom jection one-third the length of the hook (Fig. 143).

Measuremente: length of larva, 20 to $24 \mathrm{~mm}$, width at the third abdominal segment, 2.4 to $2.8 \mathrm{~mm}$; diaketer of ocsllus $2, .27$ to $.30 \mathrm{~mm}$; distance botween ocelli 1 and $2, .27$ to .29 m.; length of fronto-clypeo-labral area, 1.7 to $1.8 \mathrm{~mm}$, width, 1.7 to $1.8 \mathrm{~mm}$; length of pronotum, 1.7 to $2.0 \mathrm{~mm}$, width, 2.8 to $3.2 \mathrm{xm}$.

The lifo-history of this spefies is similar to that of c. curpurea var. graminea. The adults, howover, appear a littlo later in the spring and romain later in tho summer. Tho eggs aro laid in dry sand which contains ooro huras. The burrows vary frox ten to twenty inches in depth.

\section{C. pulchra Say.}

Color: head and pronotua dark purplo with a light groon reflection; setae on dorsal aspect of head and pronotun white, the other setae brow.

Fead: setac on dorsal aspect long, stout, and prominent; diaweter of ocellus 2 groater than the distanco between ocel11 1 and 2 ; fronto-clypeo-labral area as long as broad; U-shaped ridgo on tho caudal part of tho front bearing throe setao; antenna with the firet segment slightly shorter than the second, the third one-half and the courth slightly more than one-third the length of the 

second, the flrst segment with live or six sotas and the second with nine or ten; maxilla with the proximal segment of the galea bearing throe sotao on its mosal margin, maxillary palfus three-segmentod; labiun with " four fino sotae arrangod in a transverse row at the yontro-distal ond, proximal soguent of labial palpus with throo spino-like projections on the ventro-distal margin and with two setae on each side of these spines, the proximal segment with four sotae and the distal segment with ore.

Thorax: pronotum with the cephalomlatoral anglos extendirg as far cephalad as the mesal postion, latoral margins slightly carinate, primary oetae not large or prominent, secondary setae small and not over fifteen in number (Fig. 76).

Abdomen: chitinized arsas dietirct, secondary sotae short, small, and not numerous (Fig. 113); ninth abdomiral sternum with the caudal margin boaring two groups of four vetae each; median hook with two setae; mesal hooks with two setae, the spine-l1ke projection ons-half the length of the hook (Fig. 144). Moasurements: length of larva, 21 to $23 \mathrm{~mm}$, width at the third abdominal segment, 3.0 to $3.4 \mathrm{~mm}$; dianeter of ocellus 2, .33 to .37 m.; distance botwoen ocelli 1 and $2, .30$ to $.32 \mathrm{~mm}$; length of fronto-clypoo-labral area, 1.9 to $2.1 \mathrm{~mm}$, width. 1.9 to 2.1. mm.; length of gronotun, 2.3 to $2.5 \mathrm{~mm}$, , width, 3.7 to $4.0 \mathrm{~mm}$.

Tho larva were collected at Alberquerque, New Mexico near the upper end of an arroya in molst, adobo soll. The holos were vertical and from four to oight inchos deop. Tho identification of this spocies is not positive.

\section{Iimbata Bates.}

Color: head and pronotum bright coppery-bronze, with a groen or blue reflection; setae on dorsal aspect of hoad and pronotum white, the other setae 

brown.

Head: sotae on dorsal aspect medium in longth, slightly llattened, and prominent; dianeter of ocellus 2 distinctly greater than the distance between ocell1 1 and 2; fronto-clypoo-labral aroa as long as broad; U-ohaged ridgo on the caudal part of front boaring threo setae; antenna with the first segront slightly shorter than the second, the third a littlo more than oro-half ane the fourth one-third the length of the second, the first segment with twelve or thirteen setae and the second with nine or ton; maxilla with the proximal segment of the galoa bearing throe setae on its mesal margin, maxiliary palpus throe-segmented; labium with four fino setae arrangod in a transverso row at the ventradistal ond, proximal segment of labial palous with throe spine11ke projections on the vontro-distal margin and with two setae on each side of those spines, the proximal segzent with four sotae and the distal segment with one.

Thorax: pronotux with the cephalo-latoral angles not oxtending as far cophalad as the mosal portion, latoral margins carinate, primary sotae not large or distinct, secordary setae short, slightly flatterod, and numerous (Fig. 77).

Abdomen: chitinized areas distinct, secondary sota short, omal1, and not numerous (Fig. 114); ninth abdoinal eternum with the caudal margin bearing two grcups of throe setae each; modian hooks with throe setae; mesal hooks with two setae, the spine-11k0 projection ono-third the length of the hook (Fig. 145). Measurements: length of larva, 15 to $17 \mathrm{~mm}$., width at the third abdominal segment, 1.8 to $2.0 \mathrm{~mm}$; diameter of dcellus 2, .23 to .25 mm; distance between ocsili 1 and 2, .20 to .21 mm.; longth of fronto-clypoo-labral area, 1.45 to $1.55 \mathrm{~mm}$, width, 1.45 to $1.55 \mathrm{~mm}$; length of pronotum, 1.5 to $1.6 \mathrm{~mm}$, , width, 2.4 to $2.6 \mathrm{~mm}$.

The larvae were collected at Wray, Colorado in bare, white, sand 

blowouts. Tho burrows were straight or slightly spiral and from ten to fourt-en inchos doop and occured in clusters of a dozen or more to the squaro foot. The larvae of $\underline{\text { C. }}$ lepida were dug fron the same aituations.

Criddlo (1907) states that the larvae occur in large, sandy blowouts with scanty vegetation. They are also sometimes found on small patches of shifting soil but are always much noro plentiful in white sand which is constantly drifting. The depth of the burrows variod from seven to seventeen inches. The life-cyclo requires three years at Aweme, Manitoba, approximately two years are roguired for the larval stage and one year for the adult stage. He also states that the larva are able to sithstand much more cold than the adults, the larvae remaining out until the latter part of october.

\section{C. hirticolis Say.}

1908, Shelford, Journ. Iinn. Soc. Iond., Z001., 30, 1908, 172.- .

Color: head and pronotum bright coppery color with a greon refloctions sotae on dorsal aspect of head and proneture white, the other setae brown.

Head: setae of dorsal aspect/short, somewhat flattened, nurnerous, and prominont; diamoter of ocellus 2 slightly groater than the distance between ocelli 1 and 2; Pronto-clypoo-labral area wider than long; U-ghaped ridge on the caudal part of front bearing three setae; antenna with the first. segment Blight shorter than the second, the third throe-fourths and the fourth ono-half the length of the second, the first segment bearing seven to nine setae and the second ton to twolve; maxilla with the proximal segment of the galea bearing throe setae on its mesal margin, maxillary palpus throo-segmented; labium with four fino sotae arranged in a transverse row at the ventromistal end, proximal segment of labial palpus with three spino-like projections on the ventro-distal margin and with two sotae on each side of these spines; 

the proximal segment with four setae and the distal segment with one.

Thorax: pronotum with the cephalo-lateral angles not extending as far co chalad as the mesal portion, lateral margins lightly carinate, primary setao inconspicuous, secondary setae short, flattenod, and numorous (F1g. 57).

Abdomen: chitinized areas distinct; secondary setae short, low, and not prowinent (Fig. 93); ninth abdominal stemum with the caudal margin bearing two groups of three setae each; modian hooks with two setae; mesal hooks with two setae, the opino-like projection about ono-fourth the length of the hook (Fig. 146).

Measuremente: length of larva, 17 to $19 \mathrm{~mm}$, width at the third abdominal segment, 2.2 to $2.4 \mathrm{~mm}$; diareter of ocellus 2 , 30 to .3a mm.; distanco between ocel11 1 and $2, .27$ to $.30 \mathrm{~mm}$; length of fronto-clypeo-labral area, 1.4 to $1.6 \mathrm{~mm} .$, midth, 1.8 to $2.0 \mathrm{~mm}$; length of pronotum, 1.8 to $2.1 \mathrm{~mm}$. width, 2.9 to $3.2 \mathrm{~mm}$

The larvae of this species aro rather distinctive and easily irocognized by the large number of white, llattened or scale-1ike sotae on the pronotum. The only other larva which resembles it in this respect is C. Iimbata which has obly about hali as many sotae on the pronotum and which are not so distirctly flattoned. The larva are very restricted in thoir habitat, occuring only in cloan, moist sand which has very littlo hums. Tho burrows aro vertical and about five inches deop. The eggs are deposited in late June and July and the larvae reach the third instar sometime in september, close their burrows in October and hibernate. The burrows are opened in May of the following year and the larvae pupate in June or July. The adults emerge in Auguat, hibernato over the winter and becore sexually mature the following spring. 



\section{C. dorsalis saulcyi Guer.}

Color: head and prorotum bright coppery-bronze with a strong blue roflection; setae on dorsal aspect of hoad and pronotux transparent or glassy, the other setae brown.

Head: setac on dorsal aspect fin and incopispicuous; diameter of ocellu: 2 distinctly greater than the distance betwoen ocelli 1 and 2 ; fronto-clypoolabral area as long as broad; U-shaped ridge on the caudal part of the front boaring four or six setae, the two middle ones larger than the others; anterna with the first segment slightly shorter than the socond, the third about twothirds and the fourth one-third the length of the sedond, the first segment with five or six setae and the second with nine or ten; waxilla with the proximal eegment of the galea bearing throe setae on its mesal margin, maxillary palpus two segmented; the first and second segmerts fused, and together as long as the third segment; labium with four fine sotas on the ventro-distal ond arranged in a transverse row, proximal segment of labial palfus with threo spino-like projections on the ventro-distal margin and with two setae on each side of these spines, the proxinal segment with four sotao and the distal segment with one.

Thorax: pronotun with the cophalo-mesal portion extending distinctly cophalad of the cephalo-lateral angles, lateral margins not carinate, primary sotae srall and not consyicuous, secondary sotao short, fino and numerous (Fig. 78).

Abdomen: chitinizod areas indistinct; eecondary setae fow, short, and not conspicuous, (Fig. 115); ninth abdominal sternum with tho caudal margin boaring two groups of three sotae each; modian hooks with two setae; mesal hooks with six or soven sota, tho spino-like projection about one-fifth tho longth of the hook (Fig. 147). 

Measuroments: longth of larva, 15 to $17 \mathrm{~mm} .$, width at the third abdominal segrent, 1.4 to $1.6 \mathrm{~mm}$; diarceter of ocollus 2, .32 to .34 m.; distance botwoen ocoll1 1 and 2, .19 to .21 mre; longth of fronto-clypoomabral area, 1.25 to $1.35 \mathrm{~mm}$, width, 1.25 to $1.35 \mathrm{~mm}$; longth of pronotum, 1.5 to $1.7 \mathrm{~mm} .$, width, 2.0 to $2.2 \mathrm{~mm}$.

This spocies is oasily distinguishod by the labial palpus, which is twosogmented. This has ovidently occured thru the fusion of the first and socond segmente. The larvae wore collected at Galveston, Texas on Denver Beach from moist, clean sand outsido of the shrubs. It occurs in situations similar to those of C. hirticollis along the Now England coast and around the shores of Lake Michigan. The burrows are from twelve to eighteen inches in dopth. 

Gonus Totracha Hopo.

Head with the ridge on the caudal part of iront transverse and contir uous with the ridge on the caudal part of the vertex; antecoxal piece of the mandible distirct, crescent-shapod; cephalic margin of the labrum arcooth; ocell1 1 and 2 subequal in size, odpelli 3 and 4 not adjacent, ocell1 5 and 6 prosent; antenne separated frow the randibles by a narrow, slightly chitirized area, tho first and second and the third and fourth segments subequal in longth, the first and second twice as long as the third and fourth; maxilla with the cardo triangular and bearing one large and one small seta, lacinia absent, maxillary palpus throe-egmented, the first segment the shortest, the second and third subequal in length, the second segment with a spine-like projection on the latero-distal ond; labium not chitinized on the ventral aspect mosad and distad of tho proximal ond of the labial palpi, mosal part of the ligula concave forming a prominent carine on the lateral and caudal margins, the two setas on this depressed area lar apart, no chitinized sclerite at the proximal ond of the labial palpus, labial palpus with tho proxtmal sogment shorter than the distal segment and without spine-like projections on its ventro-distal margin, the proximal segment with six to eight setae and the distal segxent with one; Iifth abdominal segment with two pair of hooks on the dorsal aspect, the lateral hooks wanting; modian hooks straight and thorn-like and boaring a single sota; mesal hooks similar in shape to tho modian hooks, about ono-half thoir length and bearing two fine, inconspicuous setae.

This genus is represented in tho United States by two species, both of which occur in the southern and south-oastorn part. In many respects tho larvao are very closely related $t d$ the gens cicindela but they can bo separated from them by the transverse ridge on the caudal part of the front, the length of the segments of the maxillary nalpus, the sgape of the labium, the length of the 

segments of the labial palpus, and by the hooks on the fifth abdominal segment.

Table to the specios of the Genue Tetracha.

A. Diareter of ocellus 2 slightly groater than the distance botweon ocelli 1 and 2; pronotum 1008 than $4 \mathrm{~mm}$. in width, color of pronotum a dark purple; secondary setae on abdomen not numerous and found only on the

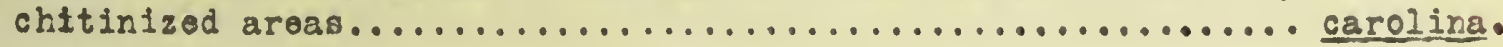

AA. Diameter of ocellus 2 slightly loss than the distance betwoen ocelli 1 and

2; pronotum 4.5 mo. or more in width, color a dark purplish-bronzo with

a green roflection; secondary setae on abdomen numerous and found botwoen

as woll as upon tho chitinized areas.................. virgirica.

T. carolina Harris.

Color: head and pronotum dark purple with a green reflection, lateral and caudal margins of pronotum pearly white; setae brown, some of those on the hoad and pronotum occasionally : whito.

Head: sotac on dorsal aspoct long, slightly llattonod, and prominent; diameter of ocellus 2 slightly greater than the distance botween ocell1 1 and 2; fronto-clypo-labral aroa longer than wido; transvoreo ridgo on tho caudal part of front with thros sotas; antenna with the first segment. slightly longer than the second, the third slightly more than one-half and the fourth alightly less than one-half the length of the second, sotac long and stout, the first segment with nine to oleven setae and the second with oleven to thirteen; maxilla with the proximal segment of the galoa boaring four sotae on its mosal margin; labium with. four fino sota at tho vontro-distal ond not in a transverse row, the two mesal setae caudad of the lateral ones, proximal egrment of the labial palpus with six or seven eetae, and tho distal segment with ono.

Thorax: pronotum with the cephalo-lateral angles oxtending cophalad of the mesal portion, lateral margins slightly carinate, primary sotao large 

and prominent, secondary sotae mall and not numerous (Fig. 80).

Abdomen: chitinized areas distinct; secondary sotae short, fine, not numorous, fow occuring botwoen tho chitinized areas (Fig. 116); modian hooks with a single prominent sotae; mesal hooks about onethelf the length of the modian hooks, with two fine, inconspicuous setae; throe prominent setao cophalad of the mesal hooks and mosad of the distal half of the modian hooks usually forming a longitudinal row.

Moasurements: longth of larva, 25 to $30 \mathrm{~mm}$, width at the third abdominal segment, 3.0 to $4.0 \mathrm{~mm}$; diameter of ocollus $2, . .40$ to $.43 \mathrm{~mm} \cdot$; distance between ocelli 1 and $2, .37$ to $.40 \mathrm{~mm}$; length of fronto-clypoo-labral area, 2.3 to $2.5 \mathrm{~mm}$, width, 2.0 to $2.2 \mathrm{~mm}$; length of pronotum, 2.4 to $2.6 \mathrm{~mm}$, , width, 3.5 to $3.8 \mathrm{~mm}$.

The larvae were collected from a variety of situations and aro not as restricted in their habitat as most of the larvae of the Cicindolidae. Dr. V. E. Shelford has dug the larvae at Galvoston and Houston, Texas and at Columbus, Goorgia. Those dug at Huston, Texas wore takon from bare, artificially oxposad soil of a fine moldy nature, not sticky. At Galvoston, Texas the larvae wore dug alorg the beach from moist sand coverod with a scattered growth of vegotation. Those collocted at Columbus, Georgia were dug from moist, clayey soil. Mr. A. H. Nane collected the larva at Southorn Pines, North Carolina from hard stony and gravely soil, clayey soil, and moist, loose, black soil. The openings to the burrows are large, the burrows straight or slightly inclined from the vertical, and from eight to twelve inches deep.

\section{T. virginica Linn.}

Color: head and pronoture very dark bronze with a green reflection, lateral and caudal margins of pronotum pearly whito; sotao brown, some of those 

on the head and pronotum occassionally white.

Head: setae on the dorsal aspect long, slightly flattenod, and prominent. diameter of ocollus 2 slightly less than tho distance botweon ocelli 1 and 2; fronto-clypoo-labral area longer than wide; transverso ridge on the caudal part of front bearing three setae; antenna with the flrst segment slight Iy longer than tho socond, the third one-half and the fourth olightly less than ono-half the length of the second, setae long and stout, the first segment with eleven to thirteon setae and the second with ten to twelvo; kaxilla with the proximal o egment of the galea bearing four sota on its mesal margin; labium with four fino setao at its ventro-distal ond not in a transverse row, the two mesal setae caudad of the lateral ones, proximal sogment of the labial palfus with five to seven setae and the distal segment with ono.

Thorax: pronotum with tho cephalo-lateral angles oxtending cephalad of the mal portion, lateral margins slightly carinate, primary setae large and prominent, secondary sota small and not numerous (Fig. 79).

Abdomen: chitinized areas distinct; secondary sotae numerous, part of them long and slender, the others short and fine and occuring botween the chitinized areas (Fig. 117); modian hooks with a single prominent sota.; mosal hooks about one-half the length of the modian hooks and with two fine, inconspicuous setae; two of the large setao cephaiad of the mesal hooks and mosad of the distal half of the median hooks usually forming a transverse or almost transverso row.

Measurements: length of larva, 28 to $30 \mathrm{~mm}$, width at the third abdominal, 4.0 to $5.0 \mathrm{~mm}$. ; diameter of ocellus $2, .40$ to $.43 \mathrm{~mm} \cdot$; distance between ocelli 1 and $2, .43$ to $.50 \mathrm{~mm}$; length of fronto-clypoo-labral area, 2.75 to 2.85 mra., width, 2.45 to 2.55 mro; longth of pronotum, 2.9 to $3.2 \mathrm{~mm}$, width 4.0 to $4.5 \mathrm{~mm}$. 

This species is similar to T. carolina but can be separated from it by its larger size, the absence of a distinct purple colcr to the pronotum, tho presence of a largo number of secondary setao on the pronotum, and the difforent arrangement of the sotas cophalad of tho mesal hooks and mosad of the distal half of the modian hooks.

The larvae were collected at Southorn Pires, North Carolina by Mr. A. H. Maneo im sandy and gravely soll, clayey soil, and in moist loose soil. They occur in the same situations a $T$. carolina and the larvae of both spocies have boen collected from tho same place. The openings to the burrows are about thre-cighths of an inch in diameter, the burrows are straight or slightly inclined from the vertical and from eight to twolve inches doop. 

Genus Omus. Esch.

Head with the ridge on the caudal part of front transverse and continuous with the ridgo on the caudal part of vertex; antecoxal pieco of the mandiblo distinct; cophalic margin of tho labrum crsnulato; ocollus 2 about one-half the size of ocellus 1 , ocolli 3 and 4 distinct, ocellus 5 small, conical, and distinct, ocollus 6 about one-half the size of ocollus 5, small, and indistinct; antenna not separated from tho mandibles by a hoavily chitinizod area, first throe sogmonts subequal in length, the fourth about ono-half the length of the second; maxilla with the cardo triangular and bearing two setao, lacinia prosent, first sogment of the maxillary palpus slightly shorter than the second and the second slightly shorter than the thira; labium not chitinized on the ventral aspect mesad and distad of the labial palpi except for a small triangular projection which extends cephalad betweon the palpigers, a distinct chitinizod sclerite at the proximal ond of the labial palpi, the first segrent of the labial palpus longer then the second and produced on its ventro-distal ond into a spine-like projection with a single stout seta on each side of the spine, proximal segment with two sotas and the distal segment with one; fifth abdominal gegnent with three pairs of hooks on the dorsal aspect, the lateral hooks present; latoral hooks short and boaring from six to oight setae; median hooks long, tho proximal half cylindrical and tho distal half thorn-like and slightly curvod ventrad, and with two sotao at about the middle; mesal hooks about onomalf the lsngth of the median hooks, the proximal two-thirds coneshapedand with two setao at its distal part, the distal ono-third thorr-chape! and projocting cepralad.

The species of this genus occur only on the Pacific coast from British Columbia to the southorn part of Califormia. Honshaw, in his chock list of 

Coleoptera, 1895, lists oloven spocies in the genus Omus. Horn (1908) lists three species and oightoen subspocies. Casey in his memoirs on the colooptera, 1914, divides the gonus into throe subgenera. In the subgenus Orus he describes forty-fivios species and subspecios.

\section{Table for Dotermining the Species of the Genus Oraus.}

A. Cephalic margin of the labrum with the crenulate emarginations deep; pronotux distinctly lighter colored than the head; tergal sclerites of the abdomen with two large, adjacent setae on the lateral margin.

californicue.

AA. Cophalic margin of the labrum with the cronulate emargination ahallow; pronotun but little, if any, lighter colored than the head; tergal oclorites of the abdomen usually with throe large, adjacent sotae on the lateral margin...

B. Cophalic margin of the labium with the modian crenulate lobe distinctly wider than those on oach oide; pronotum with more than sixty setao.

ambiguนs.

BB. Cephalic margin of the labrum with the modian crenulate lobo not distinctiy wider than those on each side; pronctum never with roore than fifty setae.......................... sequoiasum. 

Omus califorricus Esch.

Color: head dark bronze or black and uniformly colored; pronotum light cheotrut brown; setae on head and pronotum the same color as the head, the other setae light brown.

Head: setae on doreal aspect long, slender, and prowinent; diameter of ocellus 2 slightly greater than the dietance botween ocelli 1 and 2 ; fronto clygoo-labral area wider than long; transverse ridge on tho caudal fart of front boaring five setae, the middle seta wach larger than those on each side;

cophalic margin of the labmuwith the crenulate emarginations doep, the modian lobe not distinctly wider than those on each side: (Fig. 46); antenna with the first three segments subequal in length, tho fourth ono-half the lobgth of the second, the first segment bearing four or five setae and the second five or six; maxilla with the froximal segment of the galoa bearing three setae on its mesal margin; labium with four fine setas arranged in a transverse row on its ventro distal ond, proximal segment of the labial palgus with a single spine-like prom fection on the ventro-dietal margin and with a single seta on each side of this spine, the proximal gegment with two setae and the distal sogment with one.

Thorax: pronotum with the cephalo-lateral angles extendirg as far cephalad as the mesal portion, lateral margins slightly carinate, setae not moro than fourty in number (Fig. 84).

Abdomen: chitinized areas distinct; socondary sotae short and not numorcus, and with two largo, adjacent setao on tho latoral margin of tho tergal scloritos (Fig. 129); ninth abdominal stornum with the caudal margin boaring two groups of four sotao each; mesal hooks five-eighths the longth of tho modian hook and with two setae; modian hooks with two setae; latoral hooks with five to seven sotae. 

Measurements: length of larva, 26 to $28 \mathrm{~mm}$, width at the third abdoxinal segment, 3.2 to $3.4 \mathrm{~mm}$; diameter of ocellus $1, .51$ to $.54 \mathrm{~mm}$; of ocellue 2, .36 to .38 m.; distance botween ocell1 1 and 2, .2S to .31 mm.; length of fronto-clypeo-labral area, 2.4 to $2.6 \mathrm{~mm}$, width, 2.7 to $2.8 \mathrm{~mm}$; length of pronotux, 2.9 to $3.2 \mathrm{mon}$, width, 5.0 to $5.2 \mathrm{~mm}$.

The larvao were collected at Alhambra Valley, Contra Costa Co., California, Dec. 29, 1905, by Dr. F. E. Blaisdell Sr.

\section{Omus ambigure Schaupp.}

Color: head dark brown or bronze, the cephalic portion between tho mandibles lighter; pronotux dark chestnut brown, slightly lighter than tho caudal part of tho head; soteo on doreal agpect of head and pronotum dert brown, the other setae light brown.

Head: setae on dorsal aspect long, stout, and prominent; diameter of ocellus 2 equal to the distancs between ocelli 1 and 2; fronto-clygoo-labral area wider than long; transveree ridgo on the caudal part of front boaring five setae, the median seta wuch larger than those on each side; cophalic margin of the labrum with the cronulate omarginations shallow, tho modian lobe distinctly wider than those on each eide (Iig. 47); antenna with the firgt sogment elightly longer than the second, the third as long as the second and the fourth slightly more than one-ralf the length of the second, the firet segment boaring four or five setae and the second five or six; maxilla with the proximal aegment of the galea bearing throe sotae on its mosal wargin; labium with $f$ our fino setae arranged in a transverso row on tho ventro-distal ond, tho proximal sogment of the labiel falpus with a single spino-like projoction on the ventro-distal margin and with a single sota on each side of this spino, tho proximal segment with two setaeand the diatal segnent with ore. 

Thorax: pronotum with the cephala-lateral angles extending slightly cophalad of tho mesal portion, luteral margins elightly carinate, sotao moro than sixty in number (Fig. 86).

Abdomen: chitinized aroas distinct; secondary setae fairly numerous and prominent, lateral margin of tergal sclorites usually bearing throe largo, adjacont sotae (Fig. 12I); ninth abdominal sternum with tho caudal margin boaring two group of four setao oach; mosal hooks five-eighths the length of tho median hooks, and with two sotae; midian hooks with two sotae; lateral hooks with six to oight setae.

Measutemente: length of larva, 26 to $28 \mathrm{~mm}$, width at the third abdominal segment, 3.2 to $3.4 \mathrm{~mm}$; diameter of ocellus $1, .50$ to $.52 \mathrm{~mm}$, of ocellus 2, .30 to .32 mm; distance botween ocelli 1 and $2, .30$ to $.32 \mathrm{~mm}$; length of fronto-clypoo-labral area, 2.6 to $2.8 \mathrm{~mm}$, width, 2.3 to $2.5 \mathrm{~mm} \cdot$; length of pronotum, 2.7 to $2.9 \mathrm{~mm}$, width, 4.7 to $5.0 \mathrm{~mm}$.

The larva wero collected at Shatta Rotreat, Siskiyou Co., Califormia, July 31, 1905, by Dr. F. F. Blaiddell Sr. and Beverly Letcher.

Crus soquoiarum Cr.

Color: head dark bronze or black and uniformly colored; pronotum dark chestnut-brown with lighter areas; sets. on dorsal aspect of head and pronotun: the come color the head, the other sotao light brown.

Head: sotae on dorsal aspect, long, stout, and prominent; diemeter of ocellus 2 slightly greater than the distance botweon ocelli 1 and 2 ; fronto clypoo-labral area wider than long; transverse ridgo on the caudal part of front bearing five setae, the median seta much larger than those on each side; ceghalite margin of the labrum with the cronulate emarginations shallow, the median lobo 

not distinctly wider than those on oach side (Fig. 45); antenna with the first segment as long as the second, the third slightly loss and the fourth slightly more than one-half the length of the second, the first seguent with four or five setae and the socond with five or six; maxilla with the proximel soguent of the galea bearing throe setae on its mesal margin; labium with four fine seta arranged in a transverse row at its ventro-distal end, proximal zogeent of labial palpus with a single spine-like projection on its ventro-distal margin and with a single seta on each side of thio spine, proximal segment with two setae and the distal segment with one.

Thorax: pronotum with the cophalo-lateral angles extending almost as far cophalad as the mosal portion, latoral margins slightly carinate, sotae not more than ilfy in numbor (F'ig. 85).

Abdomen: chitinized areas distinct; secondary sotae fairly prominent and numerous, tergal sclerites with three large, adjacent setae on the lateral margins (Fig. 120); ninth abdominal sternum with the caudal margin bearitg two groups of four sotae each; mosal hooks five-oighths tho length of the median hooks and with two sotae; median hooks with two gotas; lateral hooks with five to seven setae.

Measurements: length of larva, 24 to $26 \mathrm{~mm}$, width at the third abdominal segment, 3.2 to $3.4 \mathrm{~mm}$; diareter of ocellus $1, .42$ to $.44 \mathrm{~mm}$, of ocellud 2. .29 to . $31 \mathrm{~mm} \cdot$; diatance botween ocolli 1 and $2, .26$ to .28 mm.j longth of fronto-clypeo-1abral area, 2.1 to $2.3 \mathrm{~mm}$, width, 2.4 to 2.6 ; longth of pronotum, 2.6 to $2.8 \mathrm{~mm}$., width, 4.0 to $4.2 \mathrm{marm}$.

The larvao were collected at Licking Fork, Hokelunno River, Califomia, at an elevation of 2900 to 3100 feet, by Dr. F. E. Blaisdell Sr. and Boverly Lotehor. 

A single larva of Omus giwardsif Cr., tho identity of which was questioned, was securod from Dr. F. F. Elaisdell Sr. This larva was collocted in the same locality as Omis sequojarfum Cr. and seem to bo identical with it. The pronotum (Fig. 87) shows a few more setae than that of O. goquoiarum (IIg. 85) but larvao of the lattor species wero observod which had a similar sota.l plan. 

Gonus Amblychila Say.

Head with the ridge on the caudal part of front transverse and continuous with the ridgo on the caudal gart of the vertex; antecoxal piece of the mandible fusod with the clypous; cophalic margin of the labrum slightly crenulate; ocollus 2 much small or than ocollus 1 , ocolli 3 and 4 adjacent, rudimantary, ocell1 5 and 6 wanting; antennes separated from the mandibles by a hoavily chitinized area, socond segment longer than all the other sogments combinod; waxilla with tho cardo triangular and boaring oight or nine sotao, lacinia absent, maxillary palpus throe-segmented, the first and second segrants subogual in length and longor than tho third, tho socond sogmont with a spine-like projoction on the latero-distal ond; labium hoavily chitinized on tho ventral aspoct mesad and distal of the proximal ond of the labial palpi, ventral aspoct of ligula concavo forming a prominent carina on tho latoral and caudal margina, the two setae on: 1 "this dopressed area close togethor, no sonarate chitinizod sclerito at the proximal ond of the labial palpus, labial palpus with the proximal segment shorter than the distal segment and witinout spinolike projections on its vontro-distal nargin, tho proximal sogment with fivs or six setas and the distal segment with twolvo to fifteon; fifth abdominal sogmont with two pair of hooks on the dorsal aspect, the lateral hooks wanting; median hooks bluntly thorn-shaped, broad at the base and with ightoen to thenty short, stout sotae; mesal hooks similar in shapo to the modian hooks, about onom half their longth, and with twelvo to fiftoon short, stout sotao.

Tho genus Amblychila includes two sposies both of which are limitod in their distribution to the south and south-central part of tho United States botmoen the Miseissippi river and the Rocky Mountains. The larvao are largor, flo.shier and more grub-like than/any of the other genera occuring in the Unitod Statea. 



\section{A. cylindriformis Say.}

Color: head and pronotum dark chostnut brown; sotao brown.

Hoad: sotac on dorsal aspoct of hoad long, slonder and prominont; ocolius 2 about one-half the diameter of ocellus 1, diametor of ocollus 2 sub-qual to the distance botwoen ocolli 1 and 2; fronto-clypoo-labral area wider than long; transvorso ridgo on tho caudal part of front with six to olght sotao; crenulatolomarginations on the cophalic edge of the labrum subogual; antenna with the second segment twice the length of the first, thres times the third and ten times the fourth, setas long and slender, the first segreent with six to twolve setae and the socond with fiftoon to twenty (Fig. 26); maxilla with tho proximal segment of the galea bearing five or six setae on its mesal margin; labium with six fine sota arranged in a trinsverse row at its vontro-distal ond, proximal segment of labial palpus with five or six sotao and the distal segment with twolvs to fifteon (Fig. 20).

Thorax: pronotum with the cephalo-lateral angles extending cophalad of the mesal portion, latoral margins slightly carinato, setao nurnerous, short and conspicuous (Fig. 81 ).

Abdomen: chitinizod areas indistinct; sotao short to long, nurerous and occuring botwoon as woll as upon tho chitinizod arsas (Fig. 123); modian hooks with eighteen to twenty setae; mesal hooks with twelvo to fifteen sotao (Fig. 148).

Measurerents: length of larva, 45 to $50 \mathrm{~mm}$, width at the third abdominal segment, 7 to $8 \mathrm{~mm}$; diameter of ocellus 1, .40 to .45 mm., of ocollus 2, .20 to $.27 \mathrm{~mm}$; distance betwoen ocoll1 1 and $2, .20$ to .24 mm.; longth of fronto-clyvoo-labral area, 3.3 to $3.4 \mathrm{~mm}$, width, 3.6 to $3.8 \mathrm{~mm}$; length of pronotum, 4.2 to $4.8 \mathrm{~mm}$, width, 6.0 to $6.4 \mathrm{~mm}$. 

The habit of the larvae, as givon by Williams and Huncorford (1913) are as follow; "They usually occur in colonios of from 2 to 11 , the individual burrows boing close together, oftor not more than 1 1/2 Inchos apart. Wsually a colony can be circunscribed by a ten inch radius......... The larger oneg (burrows) wero a littlo less than $1 / 2$ inch in dlacetor and about 30 inchos doop. The rim was slightly olovated above the surface of surrounding level, and the ontranco perfoctly c1rcular. Tho burrows havo quite a charactoristic way of going straight down for about 18 inches and then, turning to an angle of about $45^{\circ}$ downward, proceod about 18 inchos further. This lower portion has a tondancy to bo foobly spiral. The burrow for the last 10 or 8 inchos is quite noticeably onlarged, especially laterally and the extreme ond is invariably packed with the remains of former ropasts. The holes are genoraliy loceted on the brow of a cliff, but one colony was found in muddy silt at the foot of a cliff-like bank, well below the rocont flood level of the strear. Still others occursd on the high plain some half a mile back from the bluffs. Two or three were found that had their oponings in the face of the cliff. These elopod back and did not conform to the normal burrows. It was often noticed that these larval burrows were situatod near gome larger hole, as that of the field mouse or badger". 

Bibliography.

Criddlo, Norman.

1907. Habits of some Manitoba tigor bootlos (Cicindelidao). Canad. Entom., $39: 705-114$.

1910. Habits of some Manitoba tiger beotles (Cicindelidae), No. 2. Canad. Entom., 42:9-15.

Hgrn, G०O. H.

187. Descriptions of the larvas of the North American genora of Cicindelidae. Trans. Amer. Entore. Soc., 7:28-37; pl. 2.

Horn, Walther.

1908. The larvas of Amblychila and Omus. Doutsch. Entom. Zeits. pp. 285-286.

Carabidae, subfamily Cicindolinas. Genera Insectorum, 82, $1908,1910,1915,1-486$; pl8. 1-25.

Schaupp, F. G.

1878. On the Cicindelidae of the United States. Bull. Brook. Entom. Soc., 1:11-14.

1879. Lafva of Cicindolidas. Bull. Brook. Entom. Soc., 2:23-24.

1879. List of the described coleopterous larvas of the United States with some romarks on their classification. Bull. Brook. Entom. Soc., 2:1-3, 21-22, 29-30.

Sholford, R.

1907. The larva of Collyris emarginatus, Dej. Trans. Entor. Soc. Lond., 83-90; pl. 3 .

Shel ford, V. E.

1907. Prelininary note on the distribution of the tiger boetles and its relation to plant succession. Biol. Bull, 14:9-14.

1908. Life-histories and larval habits of the tiger betles (Cicindelidae). Joum. Linn. Soc. Lond., Z001., 30:157-184; pls. 23-26, fig. $1-58$.

1911. Physiological animal goography. Journ. Morgh., 22:551-618.

1912. Ecological succsssion. IV, Vegetation and the control of land animal communities. Biol. Bull., 23:59-99. 

1913. The 1ife-h1story of a bee-fly (Spogostylum anale Say.) parasite of the larva of a tiger beotlo (Cicindela scutollaris var. locontel Hald.). Ann. Entorn. Soc. Amer., 6:213-224.

1913. Animal commuties in temperate America as illustrated in the Chicago region. Chicago. $8^{\circ}$. XIII +362 p., 306 figs. .

1915. Princlplos and probloms of ecology as 1llustrated by animals. Journ. Ecology, 3:1-23. 
Plato I

Larvae, Latoral Viow.

Fig. 1. Cicindela purpurea var. limbalig.

Fig. 2. Totracha carolina.

Fig. 3. Omus californicus.

F1g. 4. Amblychila cylindriformis. 
Plato I

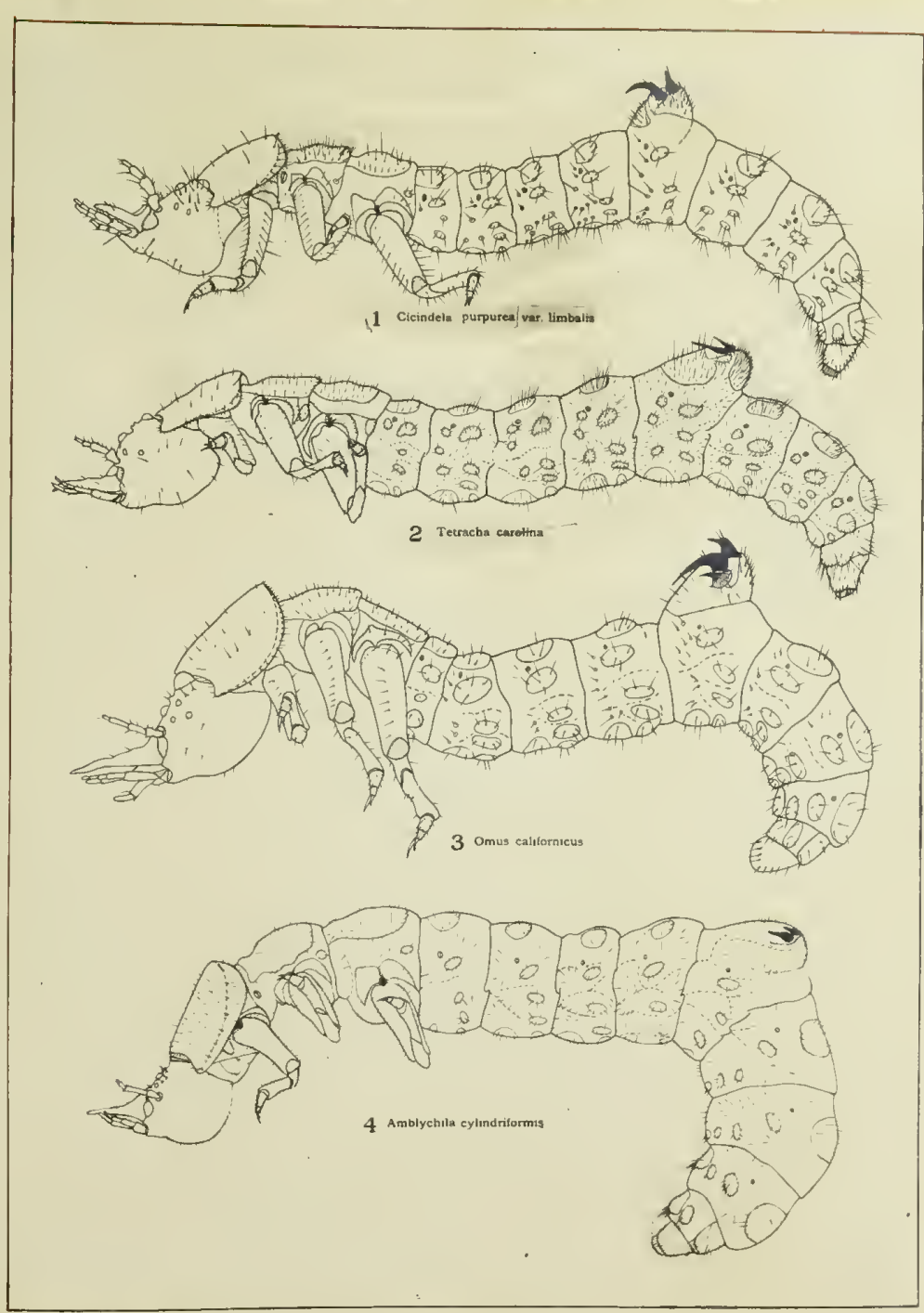




\section{Plate II}

Heads.

Fig. 5. Cicindela puroursa var. limbal18, lateral aspoct, moutrparte rerooved.

Fig. 6. Cicindola purourea var. limbalis, ontal aspoct, tentorium.

Fig. 7. Cicindela purpurea far. limbalis, ontal aspoct.

Fig. 8. Cicindela purpursa var. limbalis, dorsal aspoct.

Fig. 9. Tetracha carolina, dorsal aspoct.

Fig. 10. Amblychila cylindriformis, vontral aspoct, mouth parts romovod.

Fig. 11. Arolychlla cylindriformis, dorsal aspect.

Fig. 12. Omus californicus, dorsal aspoct.

Fig. 13. Omus californicus, vontral aspoct.

Fig. 14. Cicindela nurpursa var. limbalis, ventral aspect.

Fig. 15. Tetracha carolina, ventral aspect.

Fig. 16. Amblychila cylindriformis, vontral aspoct. 
Plate II

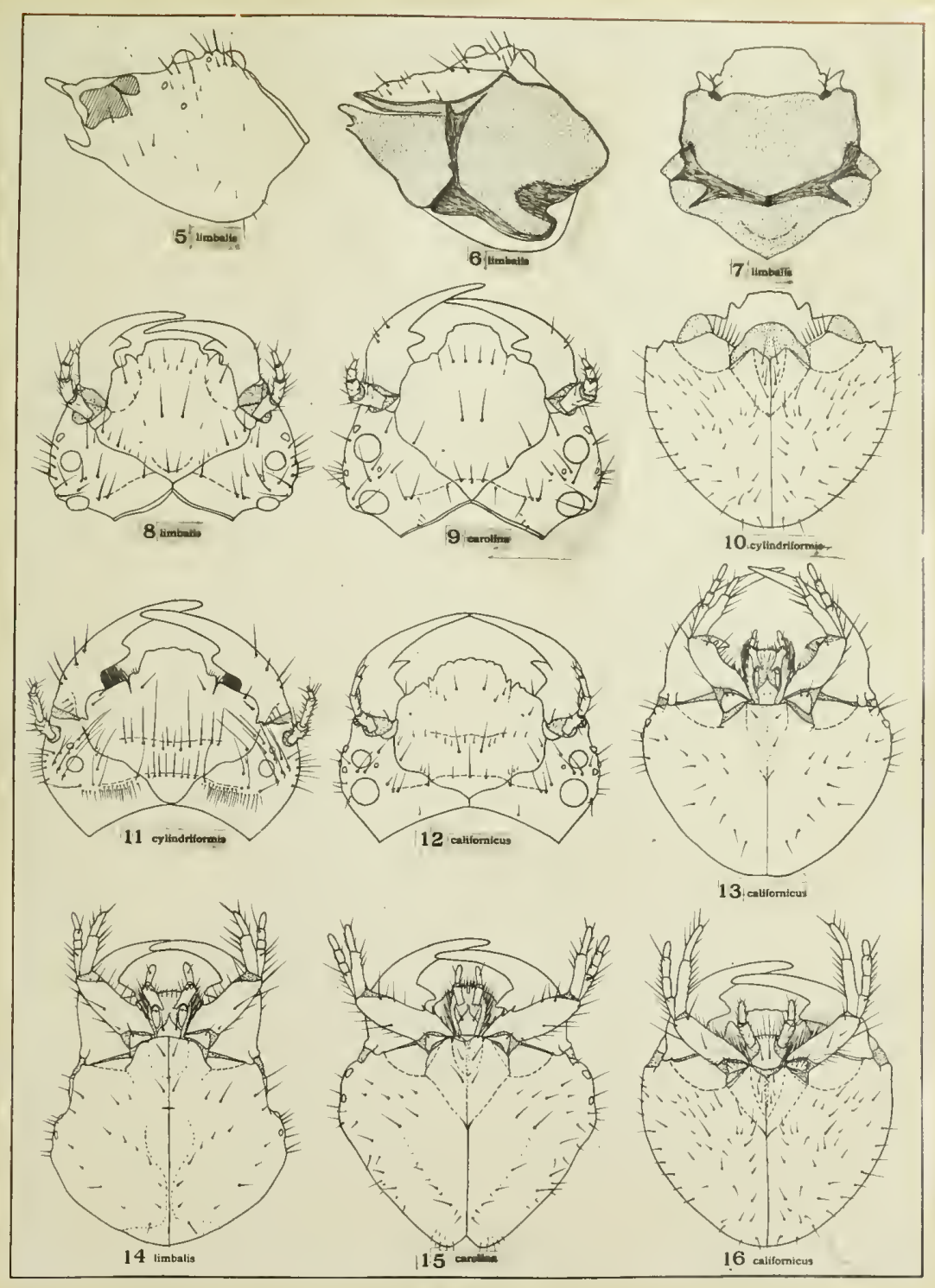




\section{Plato III}

Labia, Antennae, Maxillae, and Legs.

Fig. 17. Cicindela purpurea var. limbalis, labium, vontral aspoct.

Fig. 18. Totracha carolina, labium, ventral aspoct.

Fig. 19. Omus californicus, lablum, ventral aspect.

Fig. 20. Amblychila cylindriformis, labium, ventral aspoct.

Fig. 21. Cicindela purpursa var. Limbalis, labium, dorsal aspect.

Fig. 22. Cicindola purpurea var. Iimbalis, antonna, dorsal aspoct.

Fig. 23. Cicindela nurourea var. limbalis, antonna, vontral aspoct.

Fig. 24. Totracha carolina, antenna, dorsal aspect.

Fig. 25. Omus californicus, antonna, dorsal aspoct.

Fig. 26. Amblychila cylindriforis, antenna, dorsal aspoct.

Fig. 27. Cicindela purpursa var. Iimbalis, maxilla, dorsal aspect.

Fig. 28. Cicindela purpurea var. limbalis, maxilla, vontral aspoct.

Fig. 29. Tetracha carolina, maxilla, ventral aspect.

Fig. 30. Omus californicus, maxilla, vontral aspect.

Fig. 31. Amblychila cylindriformis, maxilla, vontral aspoct.

Fig. 32. Eicindela purpuroa var. Iirbalis, mandiblo, dorso-caudal aspoct.

Fig.,33. Cicindela purpurea var. Iimbalis, metathoracic leg, cophalic aspoct.

Fig. 34. Totracha carolina, motathoracic log, cophalic aspoct.

Fig. 35. Omus californicus, motathoracic log, cophalic aspoct.

Fig. 36. Amblychila cylindriformis, motathoracic log, cephalic aspoct. 
Plato III

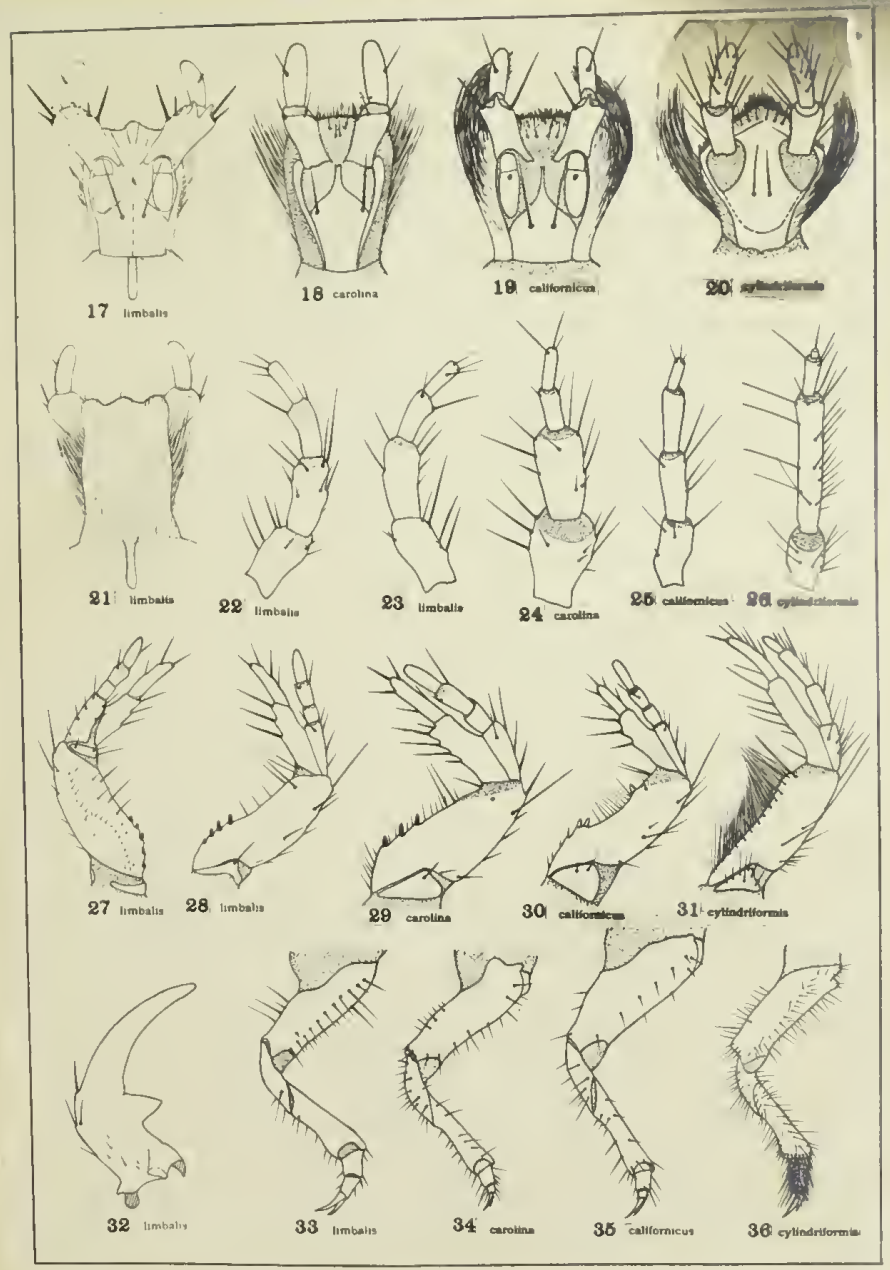


Plate IV

Thorax and Abdomen.

Fig. 37. Cicindola purpursa var. Iimbalis, thorax, dorsal aspoct.

Fig. 38. Cicindela purpursa var. limbalis, thorax, vontrel aspect.

Fig. 39. Cicindela purpurea var. Iimbalis, abdomen, dorsal aspect, segments seven to ten.

Iig. 40. Cicindela purpursa var. limbalis, fifth abdorinal segment.

Fig. 41. Arablychila cylindriformis, fifth abdominal segment.

Fig. 42. Cicindela purpurəa var. Limbalis, abdonon, ventrăl aspect, segments soven to ton.

Fig. 43. Totracha carolina, fifth abdominal sogment.

Fig. 44. Omus californicus, fifth abdominal segment.

Fig. 45. Omus sequoiarum, labrum, cephalic margin.

Fig. 46. Omus californicus, labrur, cophalic margin.

Fig. 47. Omug ambiguss, labmam, cophalic margin.

Fig. 48. Omus edwarda1i, labrum, cophalic margin. 
Pla.te IV

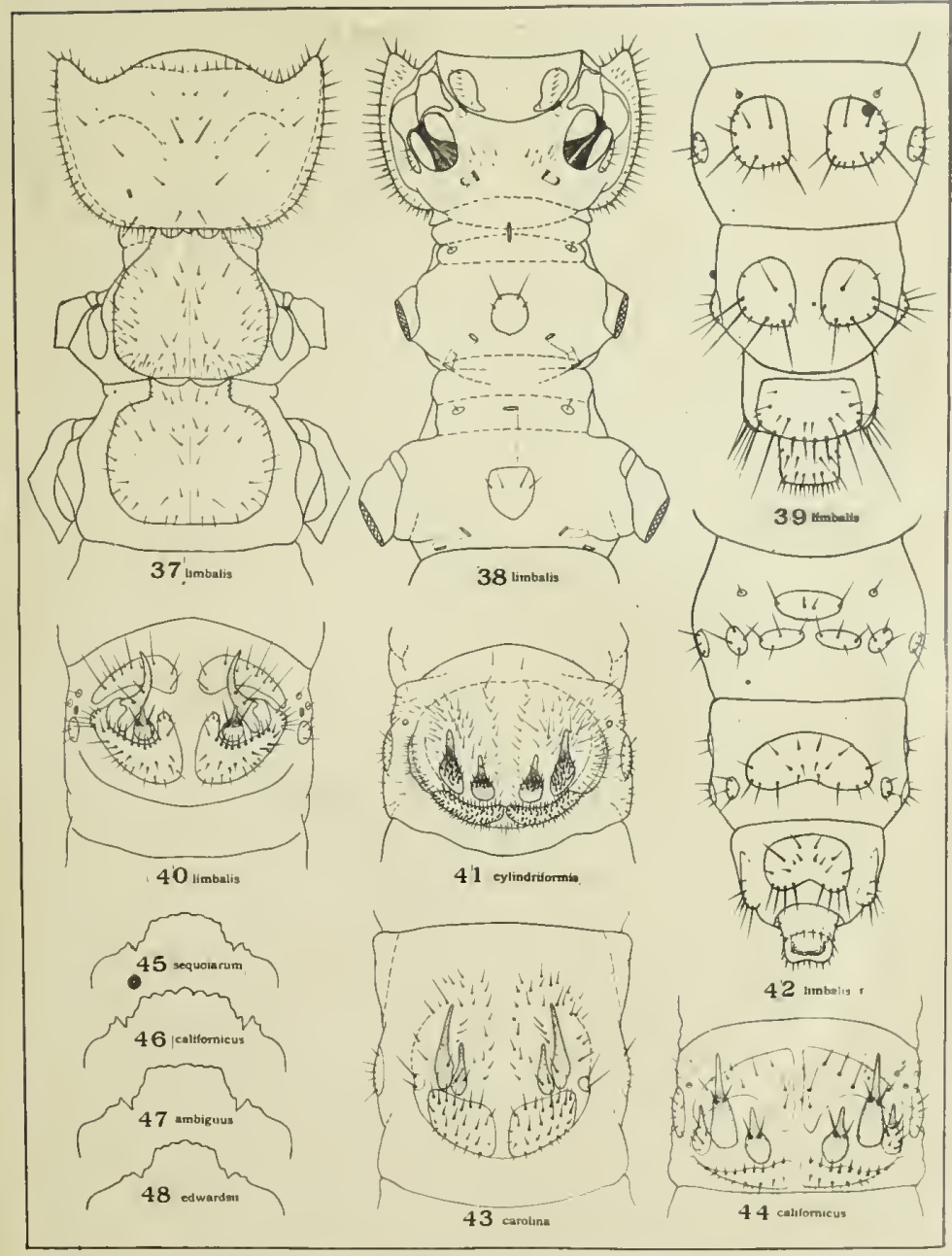


Plate V

Pronota, Setal Plans.

Fig. 49. Cicindela formoga var. genorosa, first instar.

Fig. 50. Cicindela formosa var. generosa, second instar.

Fig. 51. Cicindela formosa var. generosa, third instar.

Fig. 52. Cicindela purpursa var. limbalis, first instar.

Fig. 53. Cicindela purpursa var. limbalis, socond instar.

Fig. 54. Cicindela purpursa var. limbalis, third instar.

Fig. 55. Cicindela hirticollis, first instar.

Fig. 56. Cicindela hirticollis, second instar.

Fig. 57. Cicindela hirticollis, third instar.

Fig. 58. Cicindela 6-guttata, third instar.

Fig. 59. Cicindela sucios A, third instar.

Fig. 60. Cicindela purpurea var. graminea, third instar.

Fig. 61. Cicindela latesignata, third instar.

Fig. 62. Cicindela snocios B, thiri instar.

Fig. 63. Eicindela repanda, third instar. 


\section{Plate V}

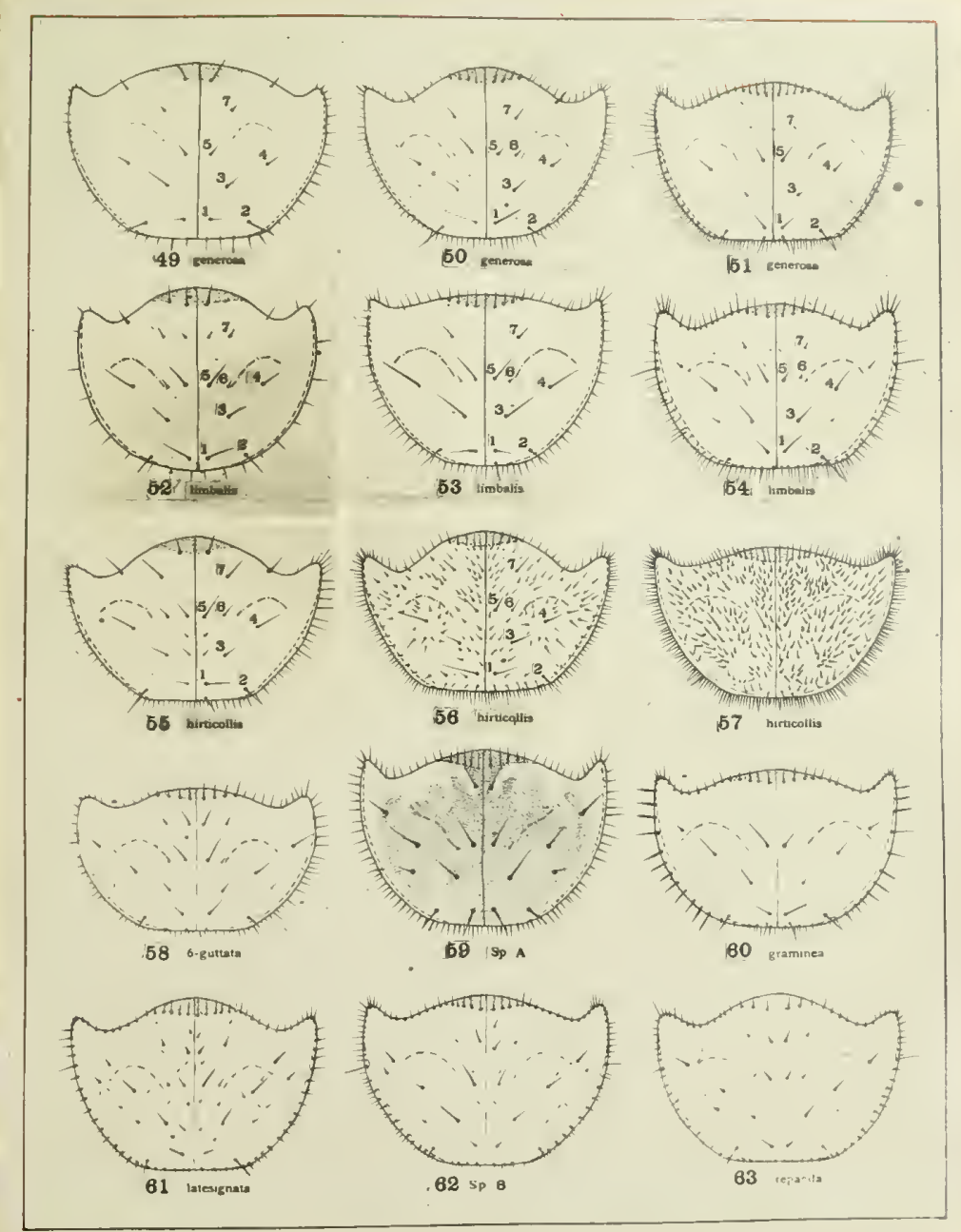




\section{Plate VI}

\section{Pronota, Sotal Plans.}

Fig. 64. Gicindela lepida, third instar.

Fig. 65. Cicindela grationa, third instar.

Fig. 66. Cicindela tranquobarica, third instar.

Fig. 67. Cicindela oregona, third instar.

Fig. 68. Cicindela 12-guttata, third instar.

Fig. 69. Cicindela nunctulata, thira instar.

Fig. 70. Cicindela flavopunctata var. rectilatera, third instar.

Fig. 71. Cicindela unipunetata, third instar.

F1g. 72. Cicindela abdominalis, third instar.

Fig. 73. Cicindela marginata, thirj instar.

Fig. 74. Cicindela formosa, third instar.

Fig. 75. Cicindela scutellaris var. lecontei, third instar.

Fig. 75. Cicindela pulchra, third instar.

Fig. 77. Cicindela limbata, third instar.

Fig. 78. Cicindela dorsalis var. saulcyi, third instar. 
Plato VI.

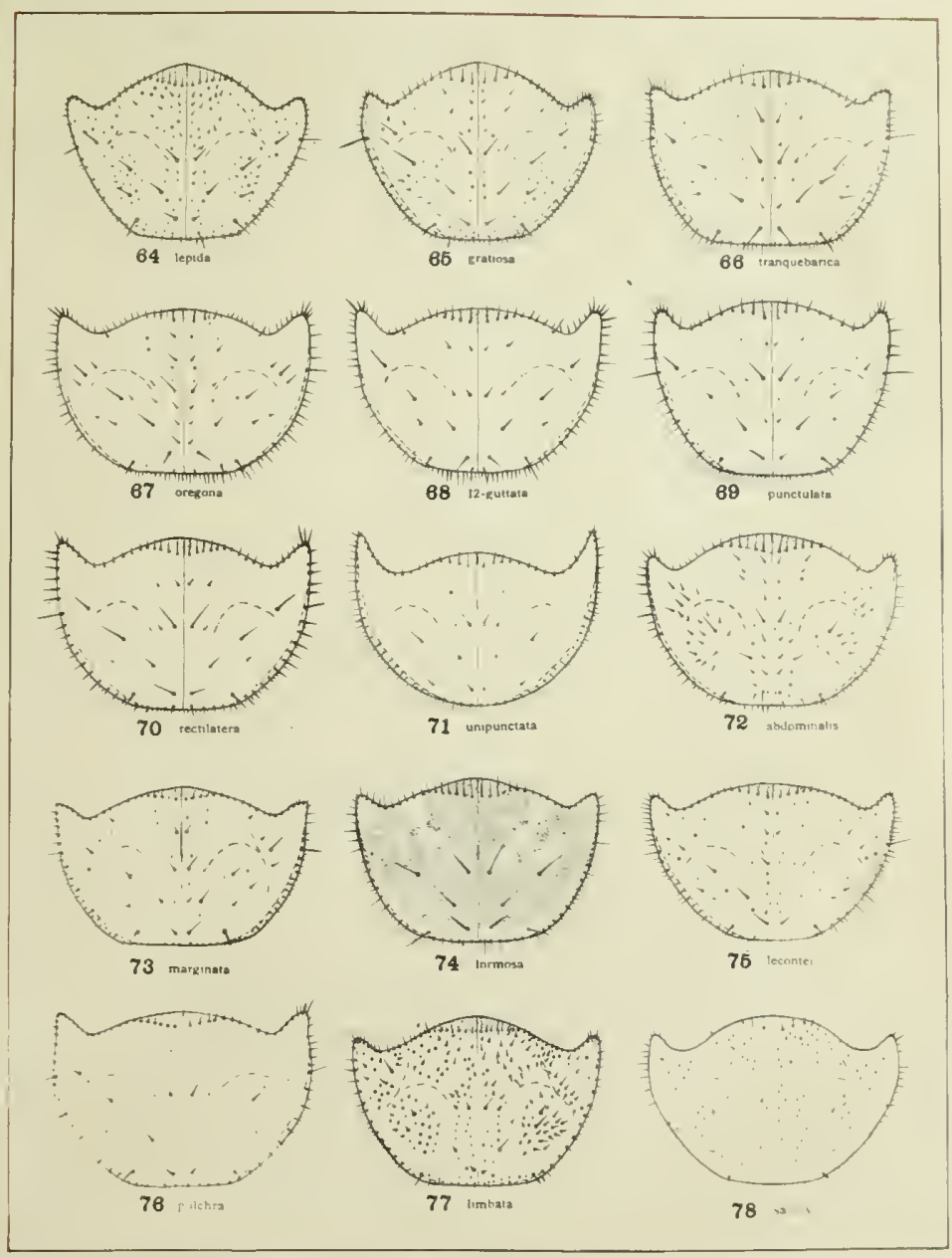


Promota, Sotal Plans.

Fig. 79. Tetracha virginica, thira instar.

Fig. 80. Totracha carolina, thira instar.

Fig. 81. Amblychila cylindriformis, thisd instar.

Fig. 82. Omus californicus, first instar.

Fig. 83. Orus californicus, second instar.

Fig. 84. Omus californicus, third instar.

Fig. 85. Omus sequolarum, third instar.

Fig. 86. Orous ambiguus, third instar.

Fig. 87. Omus edwardsii, third instar.

Third Abdominal Segment, Setal Plans.

Fig. 88. Cicindela formosa var. genorosa, first instar.

Fig. 89. Cicindela formosa var. genorosa, second instar.

Fig. 90. Cicindela formosa var. generosa, third instar.

Fig. 91. Cicindela hirticollis, first instar.

Fig. 92. Cicindela hirticolis, socond instar.

Fig. 93. Cicindela hirticollis, third in日tar.

Fig. 94. Cicindela 6-guttata, third instar.

Fig. 95. Cleindela species A, third instar.

Fig. 96. Cieindela nurpurea var. liubalis, third instar.

Fig. 97. Cicindela purpurea var. graminea, third instar.

Fig. 98. Cicindela latssignata, third instar.

Fig. 99. Cicindela spocios B, third instas. 
Plate VII

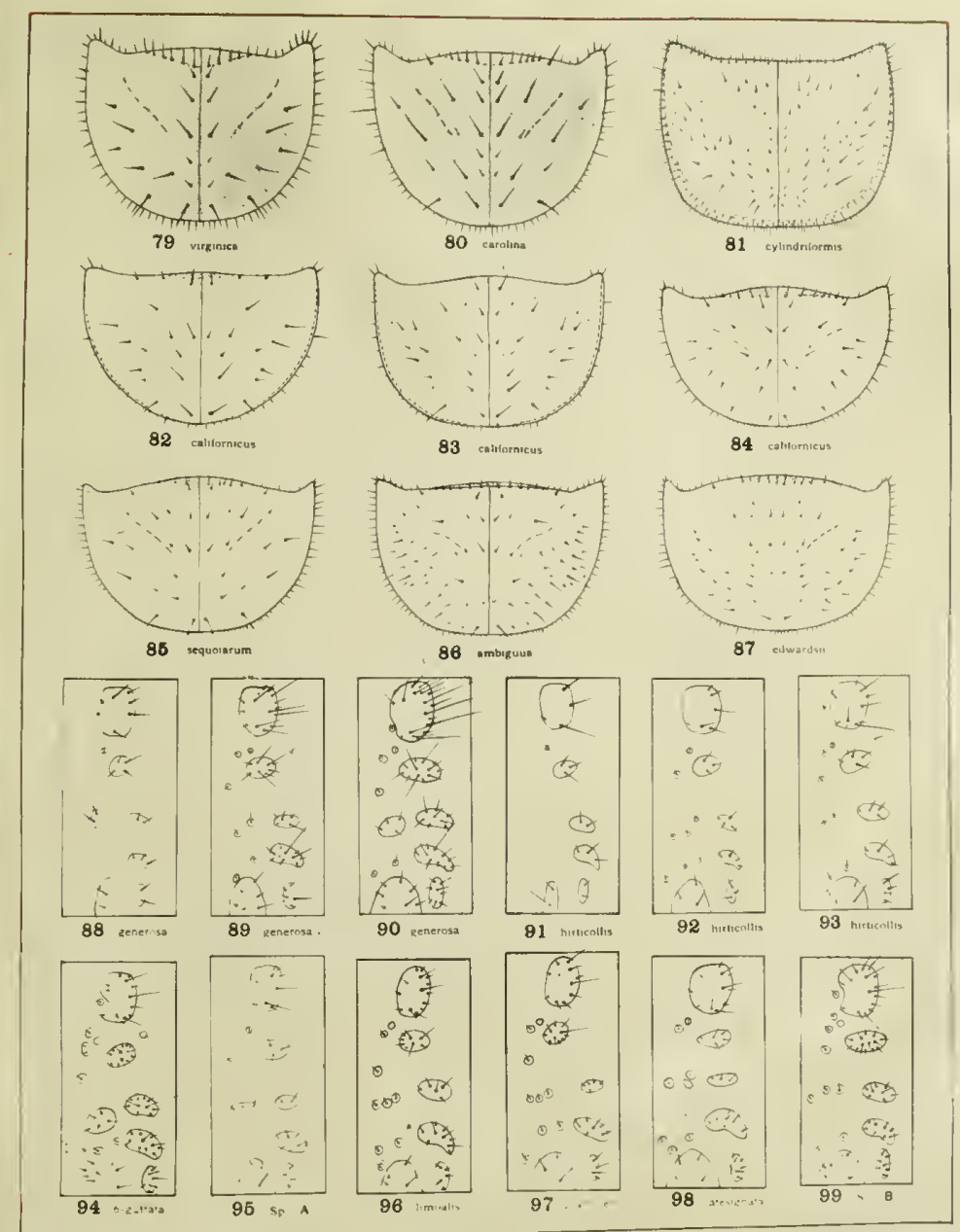


Third Abdominal Segments, Setal Plans.

Fig. 100. Cicindela repanda, third instar.

Fig. 101. Cicindela lenida, third instar.

Fig. 102. Cicindela gratiosa, third instar.

Fig. 103. Cicindela tranquebarica, third instar.

Fig. 104. Cicindela oragona, third instar.

Fig. 105. Cicindela 12-guttata, thira instar.

Fig. 106. Cicindela punctulata, third instar.

Fig. 107. Cicindela flavopunctata var. rectilatera, third instar.

Fig. 108. Cicindela unipunctata, thiri instar.

Fig. 109. Cicindela abdominalis, third instar.

Fig. 110. Cicindela marzinata, third instar.

Fig. 111. Cicindela formosa, third instar.

Fig. 112. Cicindela gcutellaris var. lecontei, third instar.

Fig. 113. Cicindela pulchra, third instar.

F1g. 114. Cicindela limbata, third instar.

Fig. 115. Cicindela dorsalis var. saulcyi, third instar.

Fig. 116. Totracha caroina, third instar.

Fig. 117. Tetracha virginica, third instar.

Fig. 118. Omus californicus, first ingtar.

Fig. 119. Omus californicus, third inotar.

Fig. 120. Omus sequoiarum, third instar.

Fig. 121. Omus ambiguus, third instar.

Fig. 122. Omes odwardsii, third instar.

Fig. 123. Amblychila cylindriformis, third instar. 


\section{Plato VIII}

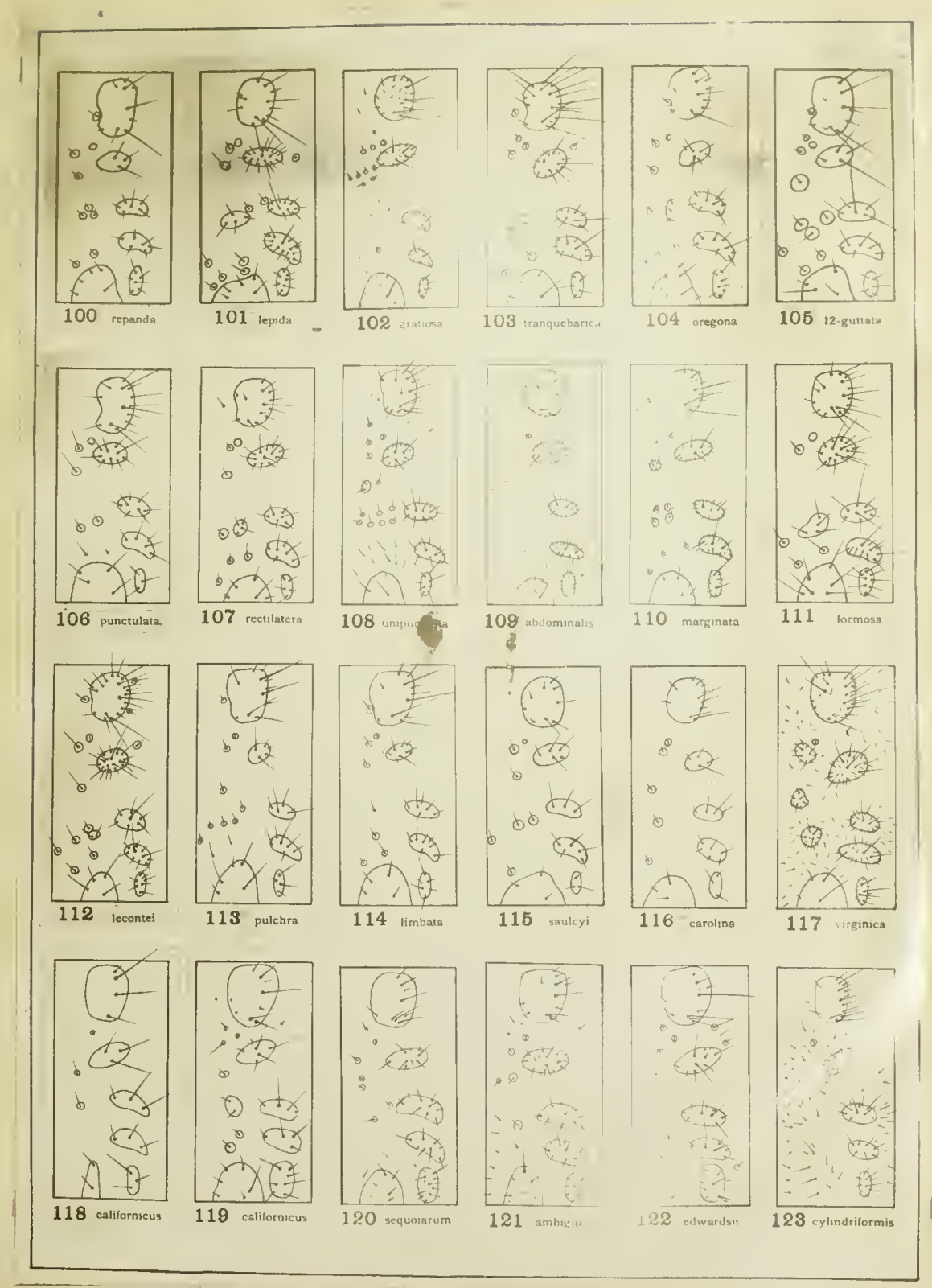


Mosal Hooks.

Fig. 124. Cicindela 6-guttata.

Fig. 125. Cicindela spocios A.

Fig. 126. Cicindela purourea var. limbalis.

Fig. 127. Cicindela purnuroa var. graminea.

Fig. 128. Cicindela latogignata.

Fig. 129. Cicindela ppocios B.

Fig. 130. Cicindela repanda.

Fig. 131. Cicindela lopida.

Fig. 132. Cicindela gratiosa.

Fig. 133. Cicindela tranquobarica.

Fig. 134. Cicindela orggona.

Fig. 135. Cicindela 12-guttata.

Fig. 136. Cicindela punctulata.

Fig. 137. Cicindela flavopunctata vas. ractilatera.

Fig. 138. Cicindela unipunctata.

Fig. 139. Cicindela abdominalis.

Fig. 140. Cicindela marginata.

Fig. 141. Cicindela formosa.

Fig. 142. Cicindola formosa var. gonorosa.

Fig. 143. Cicindela scutellaris var. locontei.

Fig. 144. Cicindela pulchra.

Fig. 145. Cicindela limbata.

Fig. 146. Cicindela hirticol1io.

Fig. 147. Cicindela dorsalis var. saulevi.

Fig. 148. Amblychila cylindriformia; $a$, mosal hook; b, modian hook. 
Plato IX

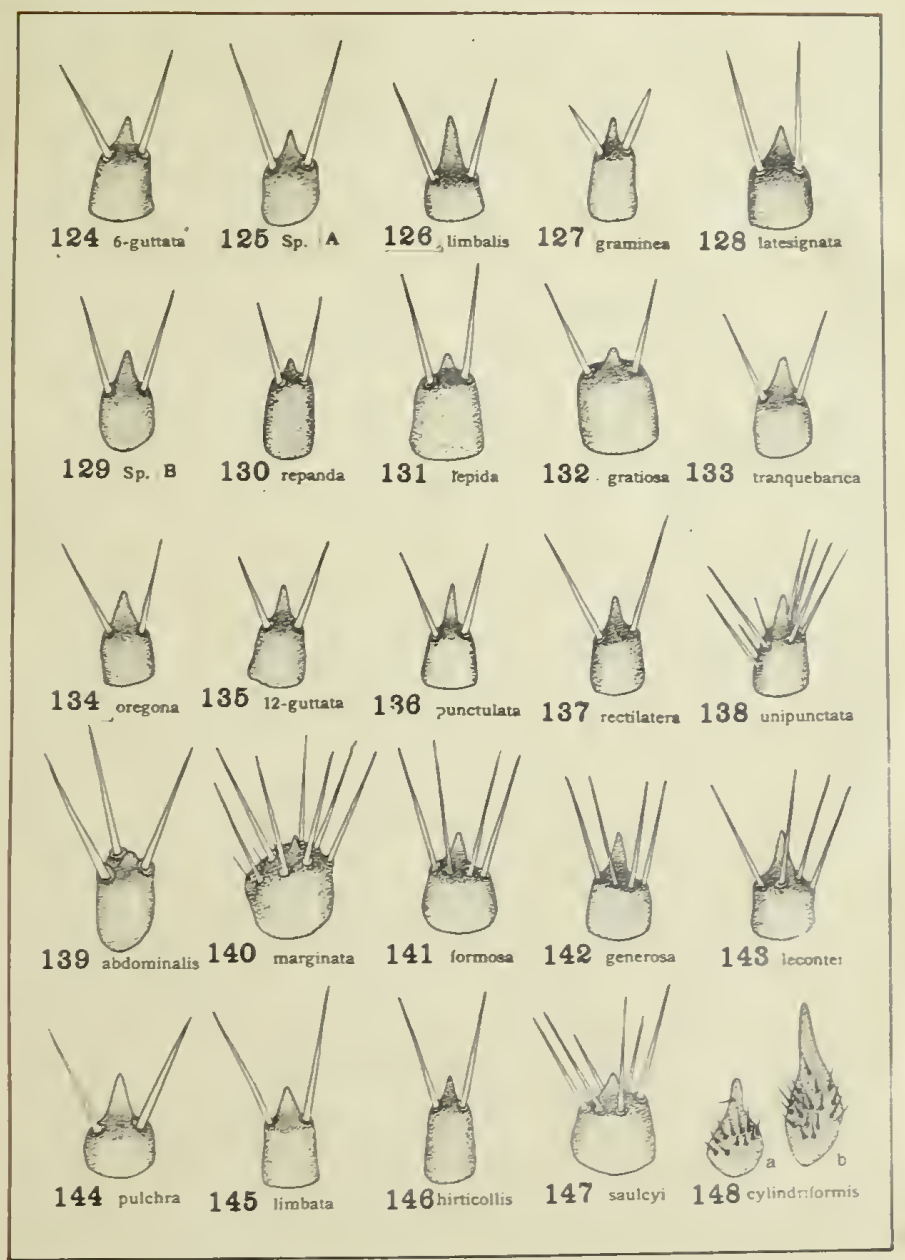




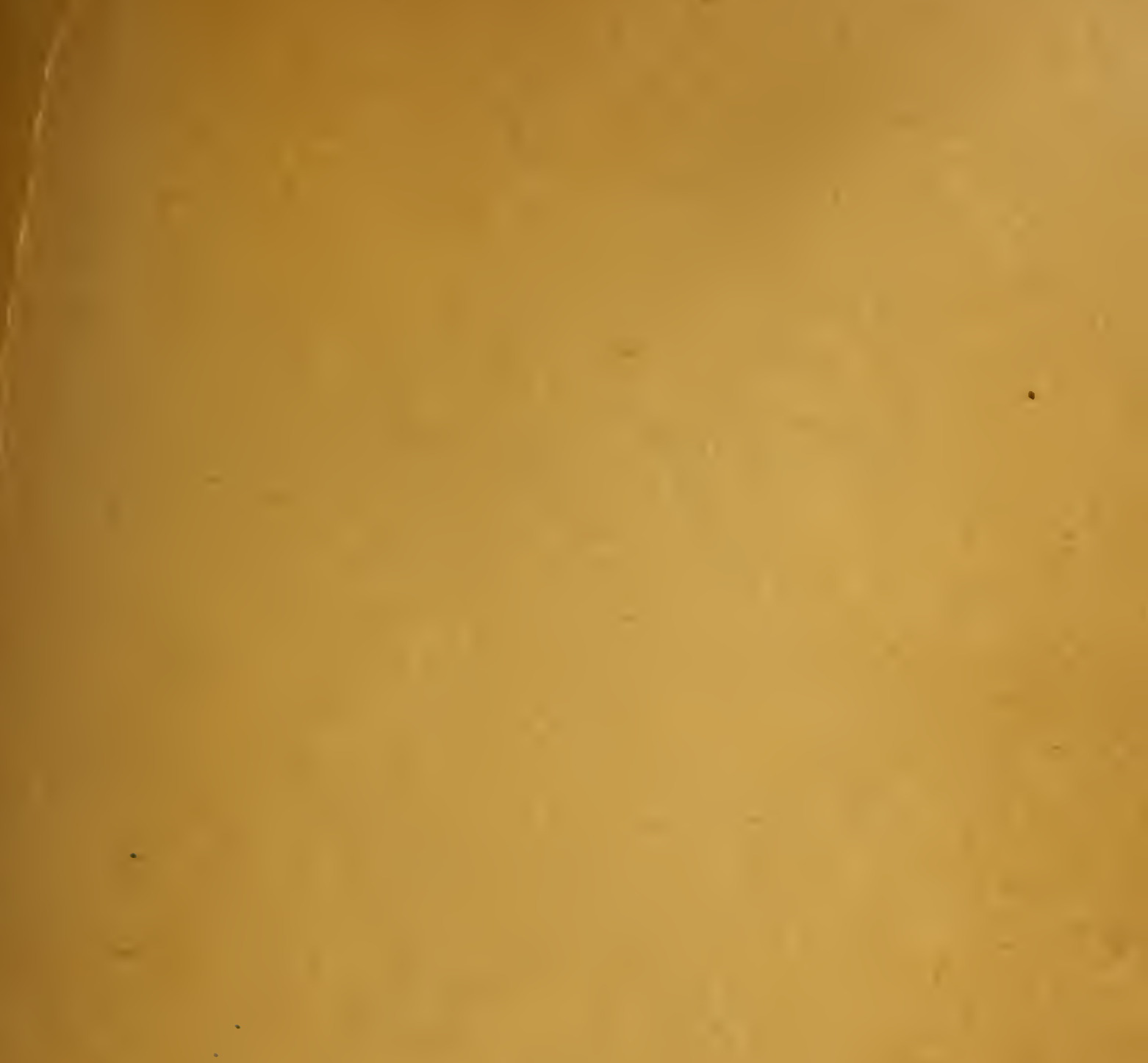

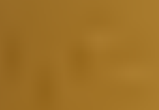

$$
i^{11}
$$

$y$

I
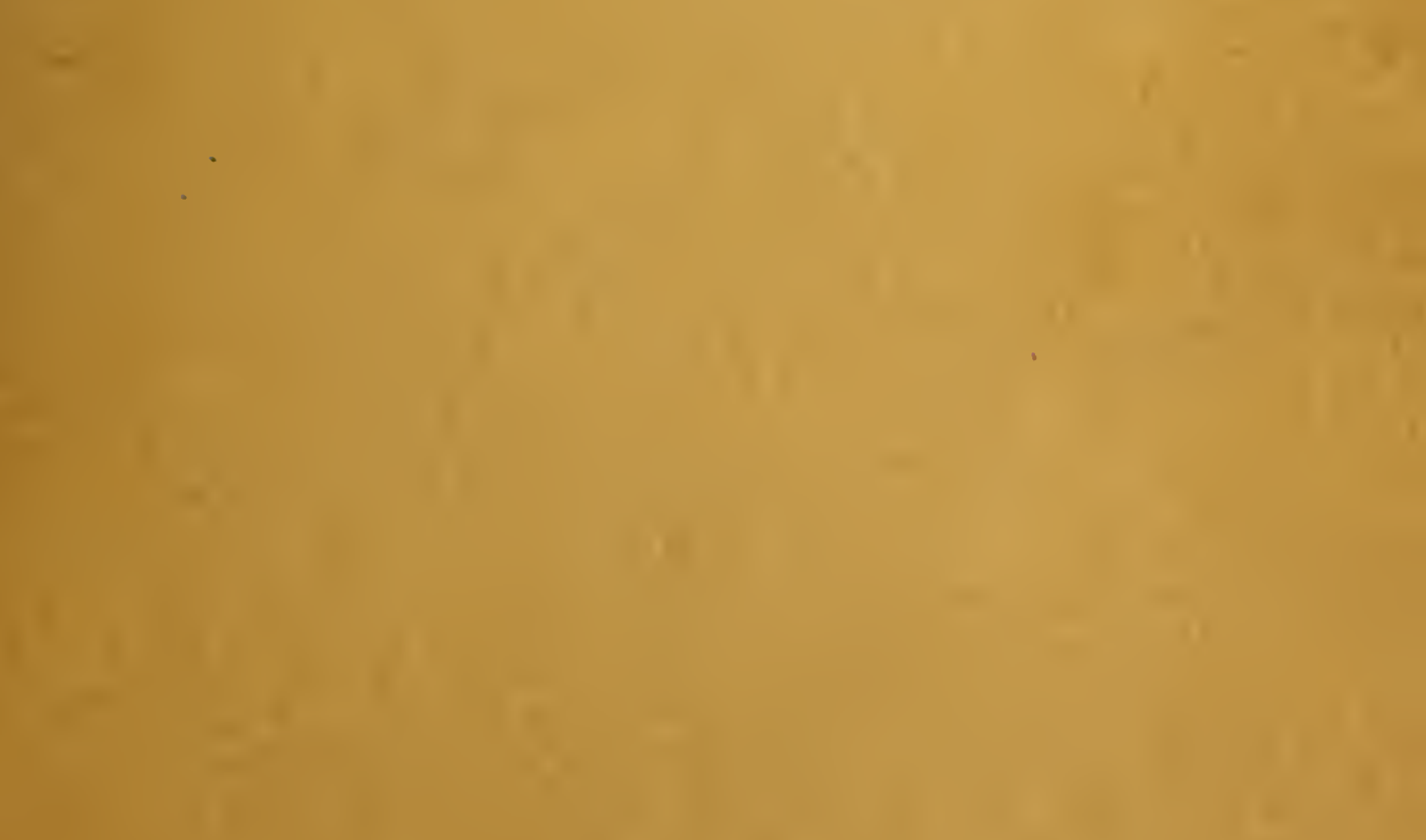

$$
-
$$


